\title{
Tufan Betimlemesi ve Sanattaki Yansımalarından Örnekler
}

\section{Dr. Öğr. Üyesi Leyla Kubat ${ }^{1^{*}}$}

Gelis tarihi: 23.10.2019

Kabul tarihi: 10.01.2019

\section{Atıf bilgisi:}

IBAD Sosyal Bilimler Dergisi

Sayı: 6 Sayfa: 221-244

Yll: 2020 Dönem: Kı̣

This article was checked by intihal.net. Similarity Index 21\%

1 Bilecik Şeyh Edebali Üniversitesi, Güzel Sanatlar ve Tasarım Fakültesi, Seramik ve Cam, Bilecik, Türkiye,

kubat.leyla@gmail.com

ORCID ID 0000-0002-4751-4055

\footnotetext{
* Sorumlu yazar
}

$\ddot{O Z Z}$

Mitoloji bilinmeyen bir zamanda ve yerde yaşanan, olağanüstü varlıklar ve olayların anlatımıdır. Manevi dünyayı ve dıs dünya ile ilișkileri de yansıtmaktadır. İnsanın varoluşundan bugüne kadar bazı büyük olaylar meydana gelmiştir. Heraklitus, Platon ve Aristoteles, geçmiște insanlığın uğradığı en büyük olayları su ve ateş felaketleri olarak ifade etmişlerdir. Su bazen yaradılışın ilk aşaması, bazen insanların cezalandırılması olarak kabul edilir. Aristo'ya göre sanatçı, gerçekten olanı değil, olabilir olanı, yani, rastlantı ve mümkün olabileni anlatandır demiştir. Olan ve olabilir olan en büyük olaylardan su ile ilgili olan tufan efsanesi, mitolojinin, dinin ve sanatın olağanüstü özellikler tașıyan konusu olmuștur. Tufan'ın meydana gelmesi neden ve sonuçları irdelendiğinde, olağan ve sosyal nitelikler içermektedir. Tufan mitleri, bölgelere özgü anlatımlar içerse de genellikle bölgesel olmaktan çok bütün dünyayı etkileyen bir olay olarak anlatılmıştır. Tufan facialara neden olurken, düzene ve inanca meydan okumaktadır. Kültürel ve dinsel bir nitelik taşıyan Tufan'ın birçok psikolojik, sosyolojik, dini, tarihi ve sanatsal yansımalarının olması da kaçınılmazdır. Bu olayları ele alan sanat dalları, farklı anlatım araçlarını kullanarak dinsel, ahlaki ve politik mesajıyla toplumu ve evrenin minimal temsilini yansılayan bir araca dönüşmüştür. İnsanın inanışa, doğaüstüne, ruhani olana, hayal gücüne bağlılı̆̆ hep olacaktır. Toplumsal devamlılığı sağlayan mitoloji, felsefenin ön temsili gibi görünse de kendisini ifade ettiği en güçlü alan sanattır. Edebiyat ve sanat dünyasında tufan daha çok kavram olarak kullanılmıştır. Çok sayıda çağdas roman ve filme konu olmuştur. İnsanın doğaya karşı üstün olduğu düşüncesi ve üstün davranışını ele almaktadır. Tufan mitolojisi sanatta, çok sık bir şekilde kullanmıștır, sanatçılar bu kaynaktan beslenmișlerdir. Bu çalışmada, sanata kaynaklık eden ve sanattın farklı dallarında konu alınan tufan efsanesi farklı kültürlerde görülmesi ve sanata dönemi bakımından önem arz eden örneklerle anlatılmaya çalıșılmıștır.

Anahtar Kelimeler: Seramik, Sanat, Mitoloji, Tufan, Doğaüstü 


\title{
Flood Descriptions and Reflections in Art
}

\author{
Assist. Prof. Dr. Leyla Kubat ${ }^{1^{*}}$
}

First received: 23.10 .2019

Accepted: 10.01 .2020

\section{Citation:}

IBAD Journal of Social Sciences

Issue: $6 \quad$ Pages: 221-244

Year: $2020 \quad$ Session: Winter

\begin{abstract}
Mitology is the narrative of extraordinary presence and event that take place in an unknown time and place. İt also reflects spiritual and its relations with the external worldSome great event have occured since human existence. Heraklitus, Platon ve Aristotle in the past the greatest event of people suffered water and fire disaster have expressed. Water is sometimes regarded as the first stage of creation, sometimes as punishment for people. According to Aristotle, the artist is the one who tells what is possible and what is possible, that is, coincidence and possible. The myth of the Great Flood, which is related to water, one of the greatest and possible events, has been an extraordinary subject of mitology, religion and art. When the causes and consequences of the Great Flood are examined, it contains ordinary and social qualities. Altough the myths of The Great Flood contain specific narrative of regions, they are described as an event that affect the whole world rather than religion. While The Great Flood causes catastrophes challanges order and belief. İt

is inevitable that The Great Flood, which has a cultural and religious quality, has many psycological, sociological, historical, religious and artistic reflection. The branches of art that deal with these event have turned into medium that reflects society, and the minimal represantation of the universe with its religious, moral and political message by using different means of expression. Man always will have faith supernatural, spiritual and imagination. Altough mitology, which provide social continuity, seems to be, the flood was mostly as a art. It has been the subject of many contemporary novels and films. It deals with the thought and superior behavior of human being superior to nature. Flood mythology has been used frequently in art, artists have been fed from this source. In this study, it is tried to explain the flood myth which is the source of art and which is the subject of different branches of art, is seen in different cultures and with examples that are important in terms of art.
\end{abstract}

This article was checked by intihal.net. Similarity Index 21\%

${ }^{1}$ Bilecik Şeyh Edebali University, Turkey, kubat.leyla@gmail.com

ORCID ID 0000-0002-4751-4055

Keywords: Ceramics, Art, Mythology, Flood, Supernatural 


\section{GíRiș}

Mitoloji "zamansızlık" ve "mekansızlık" içeren, gerçek olay ve kişileri ele alan, zaman içinde bu gerçekliği, şiirsel ve sembolik anlatımına dahil eden, Yunanca, bir nevi masal, hikaye ve söz anlamına gelen mythos ile logos kelimelerinden oluşmaktadır. Doğaüstü varlıkların eylemlerinin öyküsünü oluşturduğu ve aynı zamanda da gerçeklerle ilgili olduğundan bahsetmektedir. Mitler gelecekteki düşüncelerin esin kaynağı olarak nitelendirilerek, sanatçının anlatımında modelleştiren dünya görüşününün yorumu simgesel olarak ifade bulmaktadır.

Tufan anlatımları, temelde aynı konuya sahip fakat ortaya çıktığı coğrafyaların izlerini de taşıyarak zenginleşen ve bütün dünyayı etkileyen efsanevi mitlerdir. İtaat etmeyen inançsız toplumların yok olduğu yeryüzünün arındırılması ve inanan dürüst, masum insanlar yoluyla insan nesline ikinci bir şans verilmesi semavi dinlerde de bahsi geçen bir konudur. Tufan miti, semavi dinlerinde kutsal kitaplarda ve pagan dinlerinde efsanevi anlatımlarda yeniden varoluş ve hayata yeniden başlayışı ele almıştır. Mısır, Hindistan, Amerika, İrlanda, Kuzey Avrupa, Yunanistan, Afrika, Kuzey ve Orta Asya gibi pek çok coğrafyada tufan mitine rastlanmaktadır. Bilinen en erken örneği Mezopotamya bölgesine aittir. İnsanın yaradılışından bu yana, farklı kültürlerin aynı konuyu kendi toplumlarında ele almaları ve aktarmaları evrensel duygular içermesindendir. Sosyal kültürde hem de edebiyat ve sanat dünyasında varlığını sürdürmektedir. Mitler dünyanın, insanın ve yaşamın doğaüstü bir kökeni ve öyküsü bulunduğunu, bu öykünün de anlamlı değerli ve örnek gösterilecek nitelikte olduğunu ortaya koyar(Eliade, 1993, s.157). İnsanoğlunun hayal gücünün boyutlarını ve yaratıc1lı̆ının kaynaklarını gözler önüne sermekte, geçmiş yaşantıların çok renkli resimlerini çizmekte ve insan etkinliklerinin geleceğine yön vermektedir(Ayık, 2010, s.6). Tufan konusu anlatımında çağının özelliklerini yansıtan belirli sayıda eserle çalışma sınırlı tutulmuştur.

\section{Tufan Tanımı}

Evrenin ve insanlığın sonunu ve sonrasında ne olacağını anlatan mitlere, bu dönemde yaşanan dinin, inancın bilgiye dönüşmesine eskatoloji denmektedir. Tufan olayı, eskatoloji mitosları grubuna girmektedir. Eskatoloji düşüncenin esası yeni bir oluşumun işaretini göstermektedir. İnsanlık ya da canlılar nasıl sudan yaratılmışsa, tufanla yeniden suya dönüşmekte ve döngüsel olarak yeni bir dünya yaratılmaktadır. Tufanlar genel olarak canlıların ve dünyanın yok oluşunu ve bunun nasıl olduğunu anlatmaktadır. Bu yok oluş yokluk olarak ele alınırken, bazen de yeniden doğuş anlamına gelmektedir. Tufanla yeniden doğuş insanlığın temizliğinin ölçüsü olarak nitelendirilmektedir.

Genel olarak tufan kavramı ve tufanlarla var olan olaylar bize, insanın varolduğundan bugüne kadar yaşadıkları ile olan bilgileri aktarmaktadır. İnsanın doğayla ilişkilerini son derece azaltan uygar insandan çıkarak doğayla kucak kucağa yaşayan insana varabiliriz. Dünya gençtir; insanlar doğanın ortasında, toprağa bağlıdırlar; günlerini ağaçların, denizlerin, tepelerin, çiçeklerin arasında geçirirler (Hamilton, 1997, s.5).

Doğayla kucaklaşma yerini ölçülü olmaya, erdemli davranmaya ve toplumsal yaşamın bozulmaması için bir denge kurucu, yol gösterici, ögretici ve sonunda uyumu gerçekleştiren bir kalıp içine girmiştir. İnsana geçmişle ve gelecekle bir bağ kurma olanağı veren mitler, insanların yararlandığı ya da zarar gördüğü doğa olaylarını konu edinirken, zaman zaman da doğa olaylarının kendileri birer mit haline getirirler. Doğa olaylarından tufanın sözcük anlamı her kültürlerde kendilerine özgü farklılaşarak anlatılmıştır. Tufan sümerlerde amuru, babilde yağmur seli veya firtınası anlamında abubu'dur. Tufan, helak olmak anlamındaki tavh kelimesi ile de anlam yönünden benzerlik göstermektedir. Sözlük anlamı ise şiddetli yağmur veya seldir. Suyun taşması anlamında tuğyan kelimesi kullanılmaktadır (Aksoy, 1987, s. 8 vd.).

\section{Tufan Efsanesi Tarihine Kısa Bir Bakış}

Tufan efsaneleri, insanların yaşadığı büyük olaylar içerisinde en bilineni ve en çok anlatılanıdır. Tarihi belgelerde bu büyük felaket farklı biçimlerde aktarılsada genel olarak benzerlikler göstermektedir. Tufan efsanesi farklı dinlerde ve medeniyetlerde, farklı isimlerle görülmesine rağmen, ortak benzerlikleri edebi, tarihi, jeolojik ve arkeolojik kaynaklarla varlığı sürdürmüştür. İnsanlığın ürettiği ortak mitler arasında özel bir yere sahip olan tufan mitlerinin ikinci bir yaratılış öyküsü olduğu da kabul edilmektedir (Gezgin, 2011, s. 158). 
Yunanistan, Roma, İtalya, Anadolu, Girit, Mezopotamya, Fenike, Misır da tufan sözlü geleneklerde görülmektedir. Akdeniz çevresinde meydana gelen tufan efsanesini konu alan anonim bir resim, Amsterdam da Ruks Müzesinde sergilenmektedir. (Görsel 1)

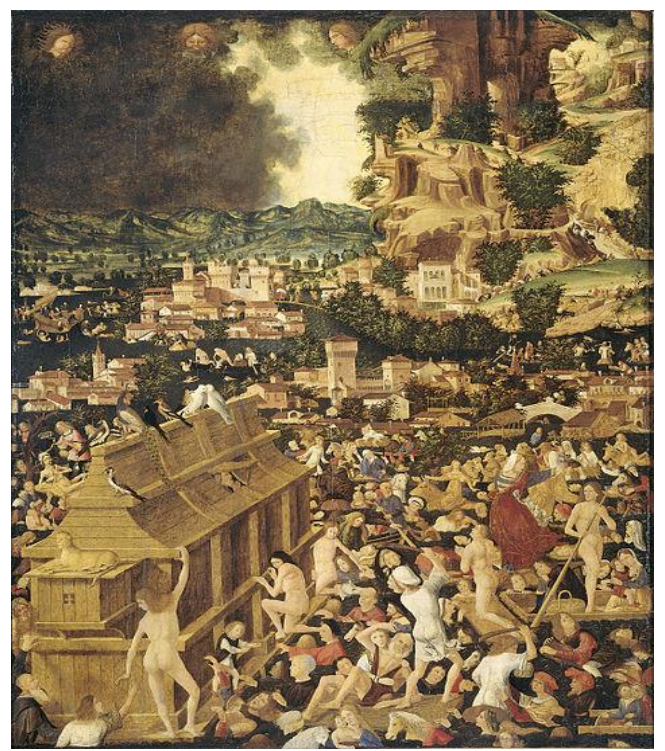

Görsel 1: Tufan, Ruks Museum, Amsterdam,1450-1499

https://www.google.com.tr/search?q=Anoniem-De_zondvloed, 09 Aralık 2015

\subsection{Sümerlerde Tufan}

Bereketli topraklarda yer alan Mezopotamya da tarih öncesinde kurulmuş ve yazılı tarihi başlatan uygarlıklar yaşamıştır. Sümerler İ.Ö. 3000 ler de Mezopotamya'ya yerlilerle kaynaşarak önemli bir uygarlık kurmuş ve yazıyı bulmuşlardır. Sümerler M.Ö.3000'den başlayarak kanunlarını yazılı kayıtlara geçirmiş uygarlıktır (Kramer, 2002, s. 46). Antik Mısır medeniyeti ile aynı tarihte yer almışlar, Akad, Asur, Babil kültürlerini etkilemişler ve kanunlar koymuşlardır. En eski tufan hikayesi olarak biline Sümer tufan hikayesi $17 \mathrm{~cm}$ kil tablet üzerine yazılmıştır. Bu tablette, M.Ö. 3000'lere ait Tufan öncesi olaylarla ilgili bilgiler ve tufan olayı şiir ve destan şeklinde anlatıldığı bilinmektedir(Kramer, 2005, s.126,127,128),(Campbell, 1998, s. 149)

Tabletteki bilgilerde Tufan memleketi kapladıktan ifadesi ile bu bölgede olduğu ve tapınakları yok ettiği anlaşılmaktadır. Boğazköy, Suriye, Filistin, Asur, Akad vb. yerlerde Huri diliyle yazılmış Gılgamış Destanı'na ait tablet parçalarının bulunması, Mezopotamya dışına kadar yayıldığını göstermektedir (Aksoy, 1987, s.47.140.144.146.). Kral Gılgamış’a ölümsüzlüğe nasıl ulaştı̆̆ını anlatmaktadır. İnsanın Gılgamış’tan bugüne kadar dünyanın kötüye gitmesinden rahatsız olduğu ve ölümsüzlüğü aradığı sanılmaktadır. 19.yy da yapılan kazılarda Sümerler ve Mezopotamyaya ait tufan farklı dillerde, farklı şekillerde yazılmış tabletler bulunmuştur. Gılgamış efsanesinin, Mezopotamya'da yaşayan diğer uygarlıklarda da farklı biçimlerle karşımıza çıkmasının yanı sıra, Herakles mitosu ve tufan hikayesine de kaynaklık ettiği düşünülmektedir. Gılgamış Destanı'nda insanlaştırılmış ögelerin olması halkın ilgisini çektiğinden, günümüze kadar ilgi görmüş, Gılgamışın sonu, insanlığın somut gerçeği benimseyip ussal bir aydınlığa adım atmasını simgeler. Ancak, bu geçiş bir ikilemin de başlangıcıdır: Ölümcüllüğü bilip, ölümsüzlüğe yatırım yapma ikilemi. Bu nedenle günümüz sanatçısının geçmişteki temsilcisidir(Madra, 2004, s. 172).

\subsection{Farklı Kültürlerde Tufan}

Yunan mitolojisinde, Deucalion mitinde Zeus insanların günah işlemesinden rahatsızlık duyarak onları cezalandırmak ister ve tufan meydana gelir. Prometheus'un oğlu Deucalion ve karısı Pyrrha kurtulur. Bu efsanede, Prometheus, oğlu Deucalion'a bir sandık yaparak, saklanmasını söylemiştir. Dokuz günden sonra tufan biter ve Parnassos dağına ayak basarlar. Zeus'tan yeni insanlar yaratmasını isterler. Zeus, ananın kemiklerini arkaya at der, Prometheus'un açıklaması ile toprağın taşlarını arkaya atarlar, o 
taşlardan kadınlar, erkekler oluşmuş yeni insan soyu türemiştir(Hamilton, 2008, s. 51). Peter Paul Rubens, Deucalion ve Pyrrha, isimli eseri ile tufan efsanesini resmetmiştir.(Görsel 2 ).

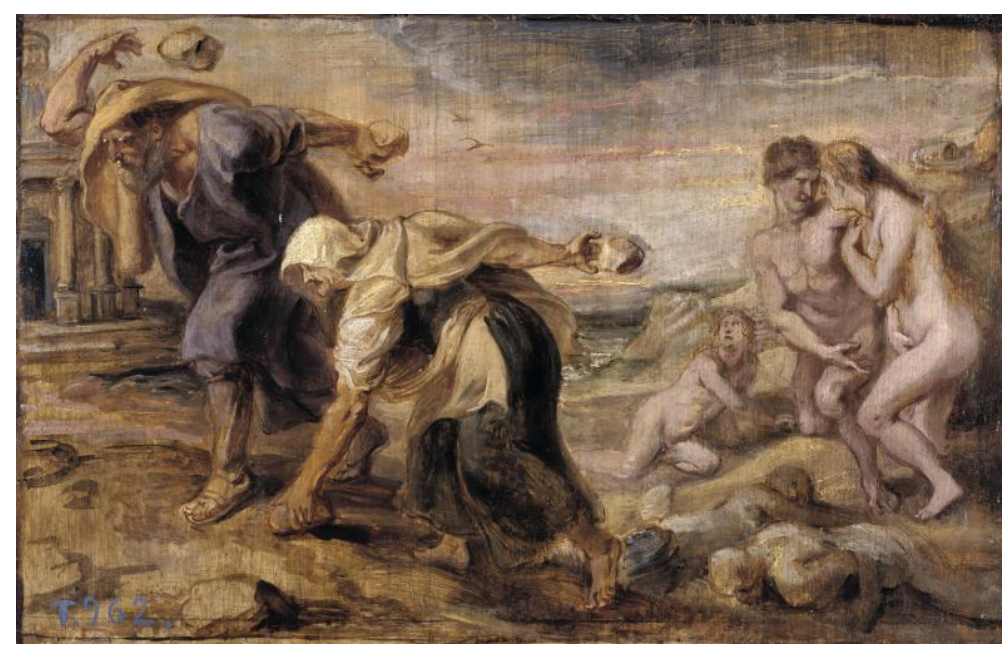

Görsel 2: Peter Paul Rubens, Deucalion ve Pyrrha, 1636, $26.5 \times 41.5 \mathrm{~cm}$ https://www.museodelprado.es/en/the-collection/art-work

Roma mitolojisinde tufan efsanesi; İnsan ırkı tarafindan başvurulan kötülüklere çok kızan Luplter insanlığı yok etmek için dünyayı ateşe vermek ister sonra bu kararından vazgeçer. Cenneti ateşe verir, dünyaya tufan ile cezalandırır. Tüm yerleri şiddetli firtına sel ve depremlerle cezalandırır. Tanrıların bu kararını bir kainin bir çifte söylemesiyle bir tekne yaparak kurtulurlar. Dünya üzerindeki tüm insanlar yaşamlarını yitirirler. Tufan bittikten sonra tekneleri yüksekçe bir tepeye oturan çiftten yeniden bir nesil meydana gelir(Şara, http://blog.milliyet.com.tr/,01.12.2016).

Görsel 3 ve 4, Hindistan'da M.Ö. 6-7. yüzyıllarında Satapatha, Brahmana ve Mahabharata destanlarında anlatılan Manu tufanı konu alınmıștır. Kral Manu insan ırkının kurucusu olarak kabul edilmektedir. Manu sabah ellerini yıkarken suyla birlikte küçük bir balık da gelir. Balık bir selin bütün canlıları yok edeceğini ancak büyürse kendisine yardım edebileceğini söyler. Küçük balık, olağanüstü bir büyüklüğe erişmiş ve Manu'ya tufanın olacağını haber vererek hemen bir gemi yapmasını, sel suları yükselince onun içine girmesini ve geminin halatını boynuzlarına bağlamasını söylemiş. (Görsel 3) Manu, pişmiş aştan hazırladığı adağını sulara atar. Adaklardan bir kadın yaratılır. Kadın, üzerinden damlalar dökülür halde ayağa kalkar. Manu bu kez evlat arzusuyla eşiyle birlikte tapınmaya ve kendini cezalandırmaya devam eder. İşte o kadın vasıtasıyla Manu'dan bir ırk türer. Bu, Manu’nun ırkıdır.

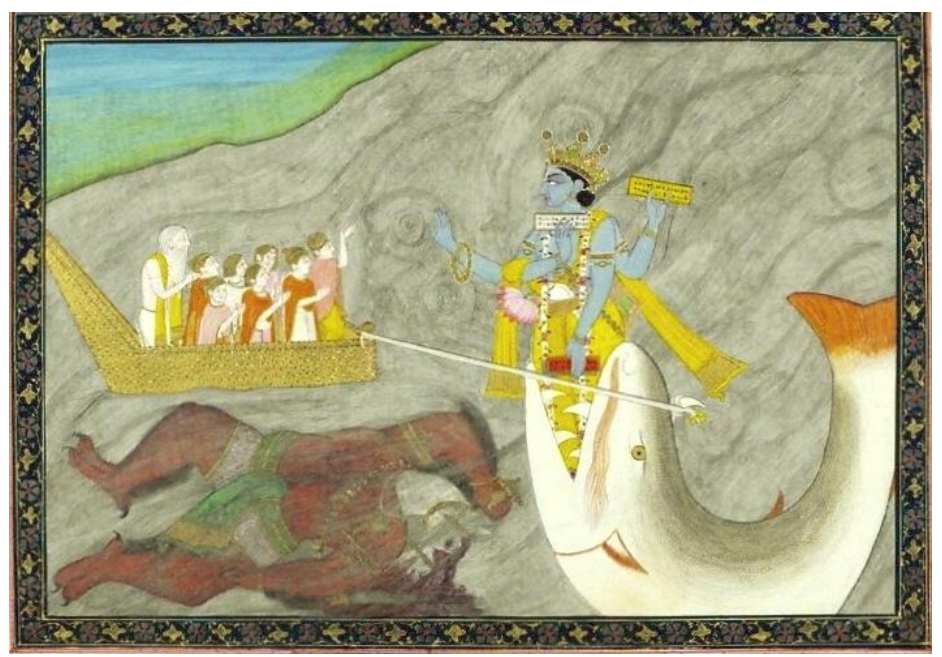


Görsel 3: Tufan, Manu'nun Teknesinin Tasviri, Lord Vishnu'nun Matsya-Avatar https://en.m.wikipedia.org/wiki/Flood_myth, 09 Aralık 2015

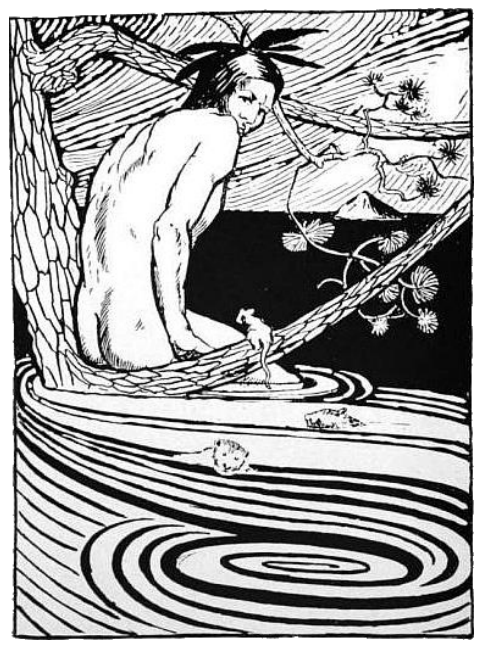

Görsel 4: Taşkın Efsanesi, Ağaçta Nanabozho, Kuzey Amerika Hint Peri Masalları Folklor ve Efsaneler Kitabı, R.C Tarafindan Yapılan İllüstrasyon, Londra: Gibbons \& Co., 1905. Sayfa 70. 1905, https://en.wikipedia.org/wiki/Flood_myth, 09 Aralık 2015

Altay Türklerinin efsanelerinde tufan miti yaşamaktadır. $\mathrm{Bu}$ efsanenin hem genelinde hem de detaylarında semavi dinlerin kutsal kitaplarda anlattıkları tufan ile ciddi paralellikler görülür. Yedi gün deprem, firtına oldu, yağmur ve dolu yağdı. Bu şekilde anlatılan tufan, sonraki süreçlerde diğer anlatılanlarla benzerlikleri ortaya koyar. Türk mitolojisinde Taşkın olarak ifade edilen tufanı, Nama'ya haber veren demir boynuzlu kök teke'dir. Onun bir gemi yapması ilhamı da yine demir boynuzlu Kök Teke'den gelir. Tanrı Ülgen Nama ve üç oğluna tahta sandık yapmasını, sekiz halatla yere bağlamasını, ailesini ve hayvanları sandığa almasını söyler. Yeryüzünü yedi gün karanlık ve sis kaplar, sular ve denizler kabarır sonunda sandığın halatı kopunca pencereden etrafa bakar ve herşeyin sular altında olduğunu görür. Nama, beraberindeki insanlığı yeniden başlatacak olan çiftlerle birlikte bir süre sonra karaya ayak basarak yeni bir insanlık deneyiminin başlangıcını yapar. İnsanlığın su ile temizlenip, başlangıçta her yerin su olmasına benzer temizlenişle tufan olayını yorumlayan Türkler, bu hadiseyi yenilenmenin bir sembolü olarak görürler. Tanrı Ülgen, insanlığın kötülüklerini su ile temizlemiş ve onlara yeni bir başlangıç için firsat vermiştir. Tufan esnasından insanın Tanrı(lar)ile mücadelesinin görülmediği Türk Tufan hikayelerinde insanlığın elde ettiği bu ikinci fırsat için Tanrı Ülgen onlara yine yardım etmiş ve yeni bir yaşam kurmak için işleri kolaylaşmıştır.

\subsection{Semavi Dinlerde Tufan}

Pagan dinlerinde olduğu gibi semavi dinlerinde de insanların yaptıkları kötülüklerden dolayı tufan felaketiyle cezalandırıldığı Tevrat, İncil ve Kuran'da da belirtilmiştir. Musevi dininin kutsal kitabının ilk yazılarını oluşturan, Babilonya'nın İbrani rahiplerinin yazdıkları metinlerde, Elohim veya Yahve/Yehova, iyi insan Nuh'a tufanı haber vermektedir. Kötülükle tanrıyı kızdıran insanlığın tufanda su ile yok oluşu, Nuh ve ailesinin tanrı yardımı ile kurtarılışı ve bu aileden insanlığın yeniden türeyişi anlatılır(Hooke, 1995, s. 156-159). Tufan efsanesinin yazılı tarihte sonlanışı, Tanrı ile ahit, Tanrının insanla yaptığı sözleşme ile hükme bağlanmıştır. Tevrat'ta tufan antlaşma ile anlatılır. Antlaşmada gökkuşağını bulutlara yerleştireceğim, bu yeryüzüyle aramdaki antlaşmanın belirtisi olacak, bütün canlıları yok eden tufan bir daha olmayacak şeklindedir. Tanrıyla insan arasındaki sözleşme, insanın uygarlık tarihinde tek tanrılı döneme geçişin yasalaşmasına işaret eden Torah, Eski Ahit olarak günümüze gelmiş̧ir (Bahadır, 2013, s.18). Eski Ahitin birinci bölümü, Musa'nın şeriat kuralları Tevrat, ikinci bölümü, Peygamberlikler ile tarihsel kitaplar ve üçüncü bölümü, şiirsel ilahiler ile düzyazı metinler olmak üzere üç bölümden oluşmaktadır. 
Tanrının Musa ile yaptığı Eski Ahit ve İsa aracılığı ile Tanrıyla yapılan Yeni Ahit, hıristiyan dünyada Roma Krallığı tarafından birleştirilmiş kutsal kitaba son şekli verilmiştir. Kutsal kitap öyküleri yüzyıllar boyu tasvirlerle anlatıla gelmiş, diğer yandan yirminci yüzyıla kadar din sanatın her alanında özelliklede plastik sanatlarda; resim, heykel, mimaride en önemli besin kaynağ 1 ve itici gücü olmuştur. Tufan farklı kültürlerde farklılıklar göstersede bilinen şekli Nuh Tufanı'dır. Tevrat'ta, Tufan, hiçbir neden sonuç ilişkisi olmadan anlatılmıştır. Neden olarak, kötülüklerin artması sonucu tanrının insanı yarattığına pişman olması gösterilmiştir. Hıristiyanlığın Kutsal Kitabının Yeni Ahit bölümü, Matta, Markos, Luka ve Yuhanna İncilleri dahil toplam 27 kitaptan oluşur. Yeni ahitte dört İncil'den ikisinde, Luka ve Matta İncillerinde ve Petrus'un mektupları bölümünde Nuh Tufanına kısaca değinilmiştir. İncil'deki tufan anlatımında; tufandan sekiz kişinin kurtulduğu, ev halkını tufandan korumak için bir geminin yapıldığı ve tufanın, bütün dünyayı etkilediği ve Tanrı tarafindan Hz. Nuh'a önceden bildirildiği de belirtilmiştir. Hıristiyanlıkta tufandan kurtuluş inananların sudan çıkarak günahtan arınması ve yeni yaşama başlayışıdır. Hıristiyanlık bu yeniden başlangıcı aynı zamanda doğal döngü, doğanın ölümü ve canlanışı gibi yaşamdaki kıştan sonra baharı yeni başlangıçları işaret etmek yönünden sembolize edilmiştir. Hıristiyanlıktaki vaftiz geleneği Musevilikten geçmiştir, bu geleneğin kökeni tufandan kurtuluş tanrıya bağlılık sayesinde yeniden doğuş olgusunun mitolojiden aktarılan simgesel anlatımıdır. Vaftiz edilerek arındırmaya gizemli bir kutsalık atfedilir. $\mathrm{Bu}$ simgesellik Hıristiyanlıkta geleneğe dönüşmüştür, sembolik bir ritüel olarak günümüze kadar gelmiştir. Hıristiyanlıkta her yeni doğan çocuk, kilisede rahip tarafından suya batırıp çıkarılarak vaftiz edilirken, günümüzde bebeğin alnına serpilen su damlacıkları ile yerine getirilen vaftiz ritüeli su ile bedeni ve ruhu arındırarak, tek tanrıya yönelme Hıristiyan topluluğa katılma seremonisi olarak modern dünyada da sürmektedir (Bahadır, 2013, s.17-31).

Dinlerde su ile temizlenme madden ve manen önemlidir. İslamiyette Allaha yönelirken ibadet için su ile abdest alınması hem fiziki hem manevi bir temizlenmedir. Kuran'ın Hûd, Nuh, Mü'minûn ve Â'râf surelerinde Nuh tufanı geniş bir şekilde anlatılmaktadır. Tufanın Kuran'da anlamı cezalandırma değil, sonraki nesillerin kurtulması şeklindedir (Çınar, 2006, s. 22,30,97). İslam sanatının anlatım dili olan minyatür sanatında Nuh tufanı bir çok eserde görülmektedir. Hz. Nuh'un gemisi, Zübdetü’t Tevârih minyatüründe, geminin sağ üst köşesinde yer alan Hz. Nuh ve ona inanan yedi oğlunun çıkan tufan karşısında gemiye yön vermeye çalışmaları konu edilmiştir. Hz. Nuh' un yüz ifadesi donuk olarak anlatılmıştır (Görsel 5). (And, 2007, s.104-113).

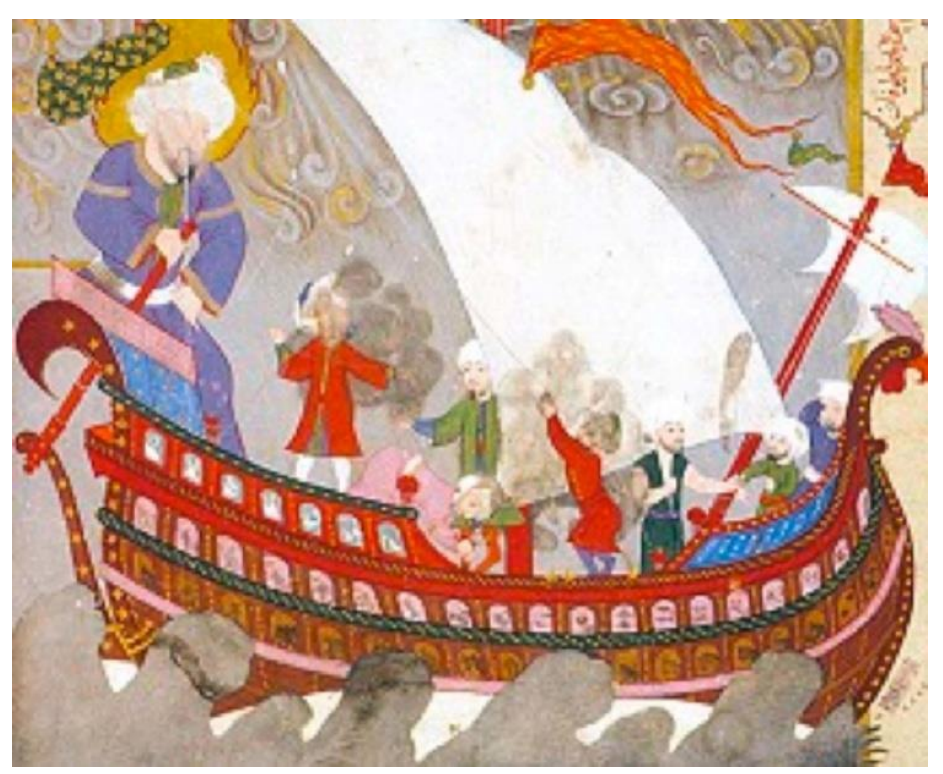

Görsel 5: Zûbdetut- Tevârih, İslam Minyatür Sanat1, Nuh'un gemisi, 56,5x32x5 cm. Kâğıt üzerine suluboya tekniği, TİEM 1973

https://www.google.com/search?q=nuhun+gemisiZ.ûbdetu+t-+Tevârih, 07.01.2019

Nişaburi tarafindan yazılan ve peygamberler tarihi olan Kısas-1 Enbiya, İslam dini tasvirlerini içeren bir eserdir. "Nuh'un Gemisi'nin Kesiti" adlı resim, tufan sonrasında geminin Cudi Dağı'nın (Ağrı/Ararat Dağı) tepesine konmuş halidir. Geminin arka kısmında kubbeyi andıran yarım daire, gri renkte dağ 
görünümü ve onun arkasında ise mavi renkli gökyüzü, gökyüzünde siyah ve beyaz bulutlarla tufanın daha bitmediği anlaşılmaktadır. Geminin üç katlı olduğu ve ikinci katında hayvanların bulunduğu, Hz. Nuh'la birlikte on iki erkek ve yedi bayan olduğu görülmektedir (Göğebakan, 2016, s.70) (Görsel 6).

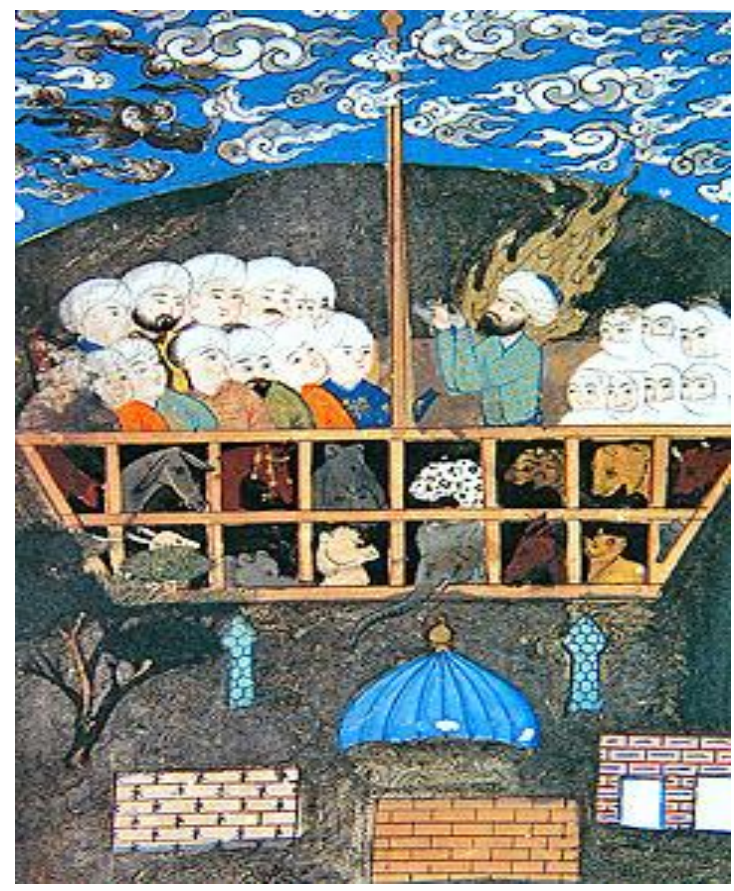

Görsel 6: Kısasü'l-Enbiya, İslam Minyatür Sanat1, Nuh'un Gemisi'nin Kesiti, https://commons.wikimedia.org/wiki/Category:Noah's_Ark_in_miniatures, 09.12. 2015

İnsanın yaşanılan felaketlerle, inançları arasında ilişki kurarak sanatsal üretime ait yaklaşımlarda bulunması ve gerçek olan ya da olmayan unsuru sanatın objesi olarak el alması birçok sanat eserinde görülmektedir. Rönesans döneminde esrarengiz ve dini konuların ele alınması dikkat çekmektedir. Sanatçıların ve düşünürlerin bu dönemde yoğun faaliyeti dikkate değerdir. Sanatla düşüncelerini aktarmaları toplumsal belleği güçlendiren en etkili yöntem olmuştur. Geçmişin kültürel birikiminin farkına varan toplumlar, sanat eserleri sayesinde varlıklarının sürekliliğini sağlamayı başarmışlardır.

Sanatta aktarılmak istenilen her zaman net bir şekilde olmaz. İmgeler, semboller ve metaforlar yardımıyla anlatılabilir (Turgut, 1990, s. 142). Tarihi araştırmalar göstermektedir ki, dinsel değerlerin sanata etkisi eşi görülmedik boyutlardadır. Avrupa tarihinin uzunca bir dönemi boyunca, Yahudi ve Hıristiyan efsaneleri tüm sanat kollarının değişmez malzemesi olmuştur(Yılmaz, 2004, s. 102). Tufan konusu tarihin hemen hemen her döneminde sanatçılar tarafindan sanat eserlerinde tercih edilmiştir. Yunan ve Roma estetiğine karşın Hıristiyanlığın kendi ideallerini ifade edebilen yeni bir estetik anlayışına sahip olması yeni tekniklerin de yoğun bir şekilde ele alınmasına neden olmuştur. Hıristiyanlığa geçişle birlikte ortaya konulan ilk resim örnekleri, katakomp denilen yer altı mağaralarda meydana getirilmiştir. Bunların genel anlamda kullanmış olduğu teknik fresk'dir. Ayrıca mozaik, vitray ve dinsel kitap resimlemeleri de Hıristiyan sanatında önemli yere sahip olmuştur.(Tansuğ, 1993).

Yüzyıllarca sanatçılara onların sanat eserlerine, kiliselere, katedrallerin tavan, pencere ve duvarlarına konu olmuş olan tufan, Nuh ve Nuh'un gemisi günümüze kadar farklı biçimlerde görülmüştür. Tufan konusunu ele alan sanatçılar Tufanı, Nuh'un Gemisi ve Yapımı, Hayvanların Girişi, Nuh Tufanı, Gemiye Güvercinin Dönüşü, Tufandan sonra Nuh'un Gemisinden Çıkışı, Nuh'un Kurban Sunusu sahnesi şeklinde eserlerinde tasvir etmişlerdir. Tufanı anlatırken kullanmış oldukları tasvirlerde anlatmak istediklerini anlatmışlardır.

Raffaello, Nuh'un Gemisinin Yapımı konusunu ele alan sanatçılardandır. Batı sanatında geminin yapımını anlatan eserler görülmektedir. Geminin yapımı sırasında Nuh'un oğullarına nasıl yapmaları gerektiği biçimindeki ifadeleri, kutsal kitapta anlatıldığı şekilde 'gofer' ağacını ve onun şekillendirilmesi 
ile ilgili sahneleri, geminin yapımı betimlenmiştir(Tükel ve Arsal, 2014, s. 25). Raffaello, Rönesans ruhunu yansıtan Nuh'un gemisinin yapımı freskinde, Nuh'un elini uzatarak işaret etmesi onun bilgeliğini ve ustalığını, gemiyi kendisinin yaptığını, geminin yapımında da üç oğlunun da kendisine yardım ettiği şeklinde tasvir edilmiştir. (Görsel 7)

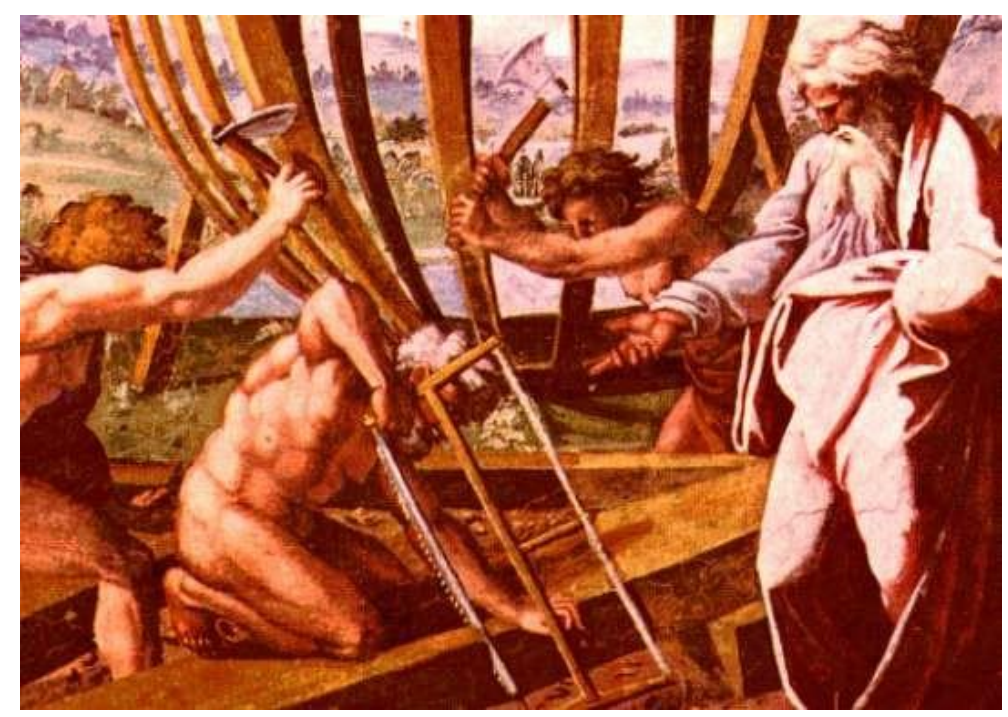

Görsel 7: Raffaello Sanzio, Nuh'un Gemisinin Yapımı, Vatikan Pontifici Sarayı, Fresk, 1517-19 https://www.google.com/search?q= Raffaello+Sanzio,+Vaticano+Pontifici+Saray1, 09.12. 2015

İnsan ve hayvan figürlerinin yaşama yakın niteliklerini vurgulayan Maniyerist üslubun önemli isimlerinden olan İtalyan ressam Jacoppo Bassano'nun, Nuh'un Gemisinin Yapımı adlı resminde Ararat dağını kaplayan bulutlar tufanın yaşlaştığını göstermektedir. (Görsel 8)

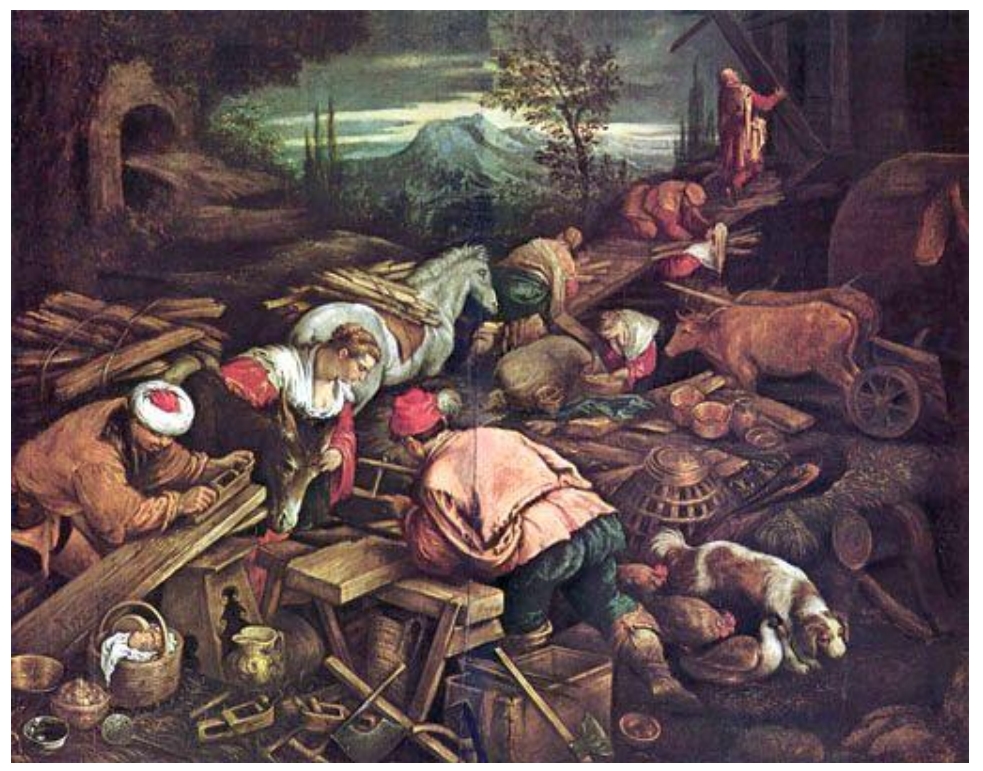

Görsel 8: Jacoppo Bassano, Nuh’un Gemisinin Yapımı,124x163 cm. Tuval Üzerine Yağlıboya, 16. yy. Museedes Beaux-Arts, Marsilya, Fransa, https://www.unique-canvas.com/artprints/jacopo

Madrid'de Prado Müzesinde, Jacoppo Bassano tarafindan yapılan, Nuh'un Gemisine Hayvanların Girişi konusunu tablosunda ele almıştır. Tabloda geminin bir bölümü, Nuh ve ailesi, hayvanları sırayla gemiye sokmaya çalıştı̆̆ı ve hayvanların çift olduğu gösterilmiştir. Gemiye hayvanların girişi sırasında 
hayvanların hareketi ortamdaki korku ve endişeyi hissettirmektedir. Kırmızı pelerinli figür Nuh'u simgelemekte ve bulutların hareketi tufanın yaklaştığını düşündürmektedir. (Görsel 9)

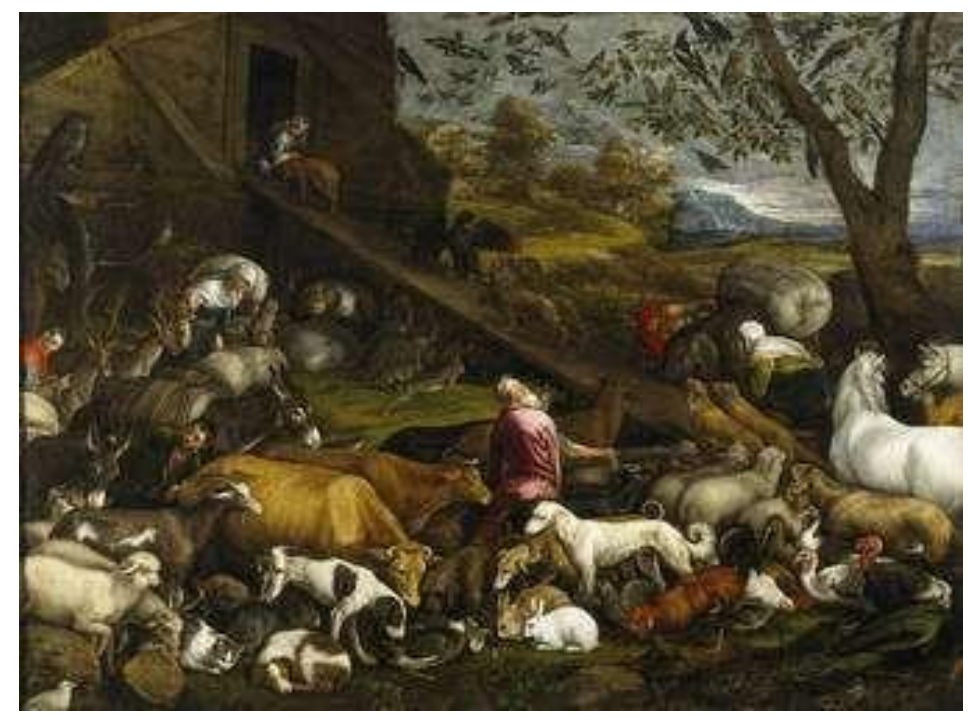

Görsel 9: Jacoppo Bassano, Nuh’un Gemisine Hayvanların Girişi, Madrid Prado Müzesi, İspanya, Yağliboya, 1570,

http: //www.museodelprado.es/en/the-collectin/online-gallery, 09.12. 2015

Görsel 10' da dini konular üzerinde çalışan bir ressam olarak bilinen İngiliz ressam John Martin, Nuh tufanı, Büyük Günün Gazabı adlı eserlerinde tufan konusunu ele almıştır. Dalgaların hareketi ile tufanın dehşetini ve yeryüzündeki her şeyi yutacakmış etkisi ve dalgalarla gögün birbirine girmiş anlatımı ile güçlendirilmiştir. Tanrının insanlığı cezalandırmasını dalgalarla boğuşan teknenin hareketli eğriliği ile kontrasttır. Tufan konulu resimlerde gördügümüz gemi formları ile örtüşmeyen bu yelkenli tekne, Nuh'un Gemisi'nden çok Ortaçağ savaş teknelerini çağrıştırmaktadır. Mavinin açıktan koyuya geçişin egemen olduğu resimde özellikle alt kısımdaki turuncunun düşük kroması ve tonları kontrast renk armonisini oluşturmaktadır (Sezer,2017, s.67).

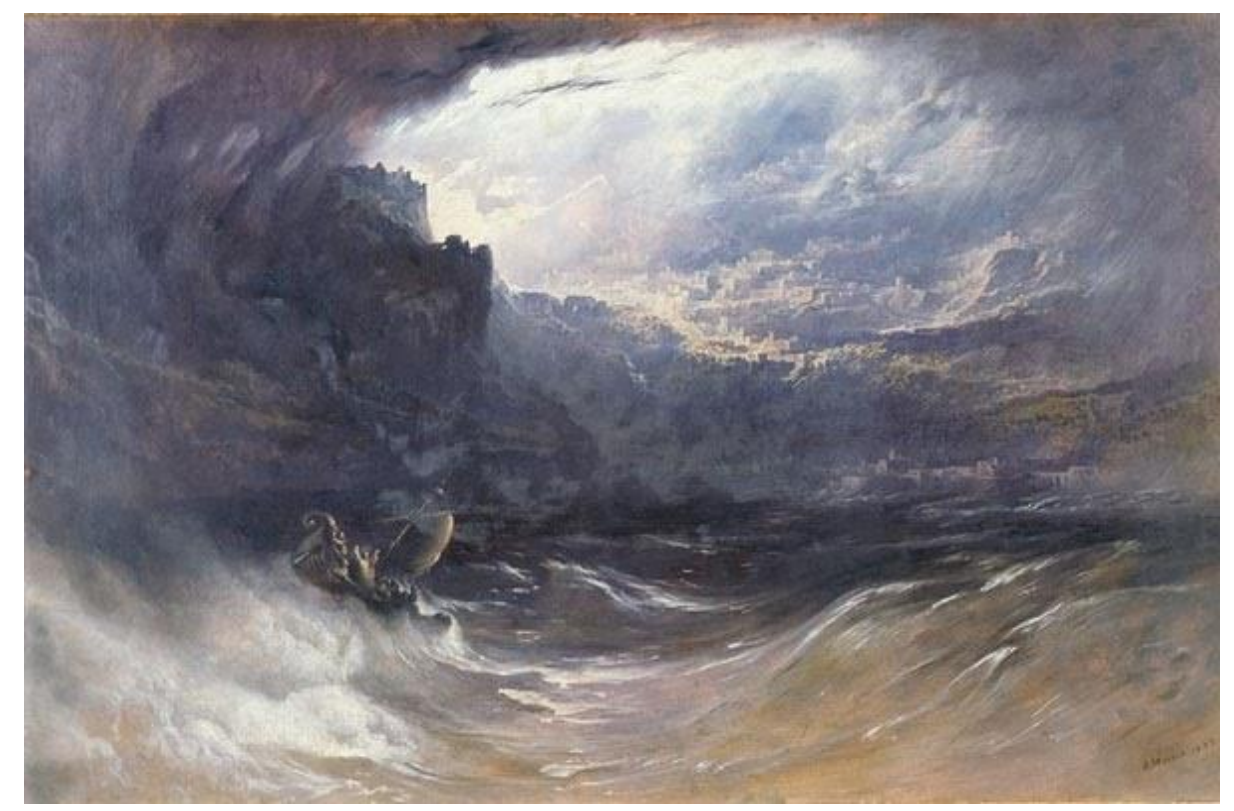

Görsel 10: John Martin, Tufan, Yale University, Tuval, Yağlı Boya, 168 x 258 cm, 1834 https://tr.wikipedia.org/wiki/Dosya:Martin,_John, The_Deluge,1834.jpg, 09 Aralık 2015 
Vatikan'da Michelangelo Buonarroti, Sistine Şapel tavanına, Nuh Tufanını ayrıntılı olarak işlemiş ve tasvir etmiş en iyi kompozisyondur. Yükselen sudan güvende olmayı uman, umutsuz insanların dağın tepesine tırmanışını, diğer bir grubun yağmurdan sığınmak istemesini ve selden kurtulabilen tek gemi Nuh'un gemisine ulaşmaya çalışan insanları, tufanı farklı bir duygu yükleyerek insanların yüz ifadelerinde felaket anındaki kaygı, korku, telaş, kaçış, ızdırap çekmelerine rağmen azimle mücadele etmelerini tasvir etmiştir. Kurumuş ağaç tufan sahnesinde sembolik olarak ölümü anlatılmıştır. Michelangelo'ın değişen dünya görüşü ve yorumların vaolan geleneğe tepkiyi anlatmak için insanları çıplak olarak tasvir ettiği bilinmektedir. Bununla birlikte resim sanatının gelişmesinde çığır açan bireyselliğin öne çıkışı değişim sürecinin başlangıcı olmuştur. Değişimin sanata yansıması Michelangelo'dan etkilenen çağdaş yorumlayıcısı Raphaello'nun, Vatikan sarayındaki fresklerde Tufan sahnesinde de görülmektedir.(Görsel 11)

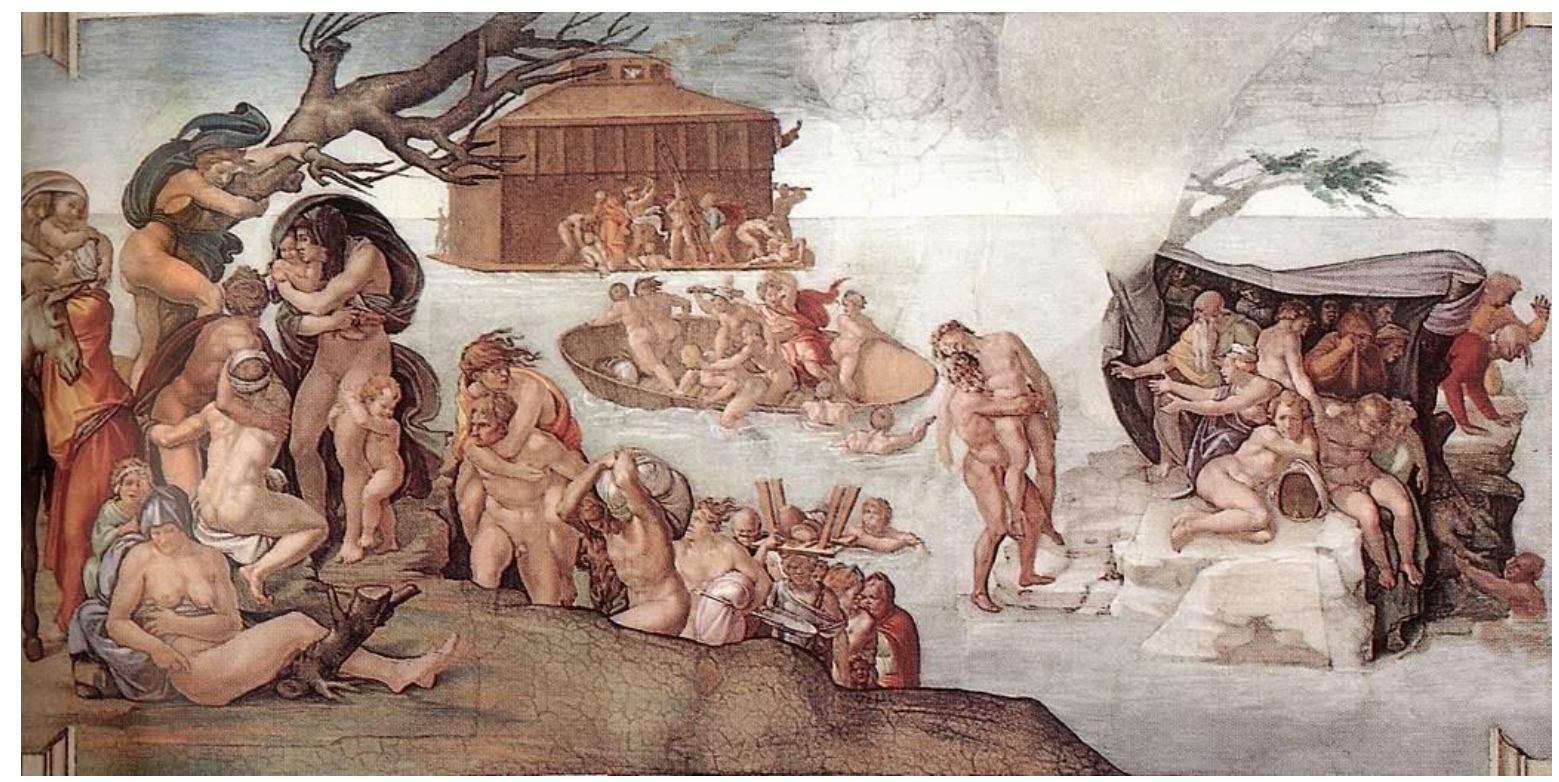

Görsel 11: Michelangelo Buonarroti, Nuh Tufanı, Fresko, 280×560 cm, Museum Sistine Şapeli Tavanı, Vatikan,1508-1512, http://www.artbible.info/art/large/71.h, 09.12. 2015

Fransız ressam, baskı resim ve illustrator sanatçısı Gustav Dore'nin, Tufan isimli gravür baskısında canlandıran Nuh'un gemisi yükselen sularda uzaklaşırken, Nuh ve ailesi tufandan kurtulur, geride kalanların tufanla mücadelesi ve yok olması tasvir edilmektedir. (Görsel 12-13) İnsanların yavrularını kurtarma çabası anlatılmaktadır. Sudaki çocuğunu kurtarmak isteyen babanın onu omuzuna alması, bir diğer babanın kayanın üzerine çocuğunu bırakması, diğer taraftanda eşini kurtarmak için olan mücadelesi aktarılmışırır. Kayanın üzerinde yavrusunu ağzına almış, aslan bulunmaktadır. Siyah beyaz baskıresim çalışmasında figürler üzerine gelen ay ışı̆̆ı ile aydınlanan insan vücutlarının anatomik yapısındaki güçlü anlatım detayların aktarılması ile sağlanmıştır(Sezer, 2017, s.72). 

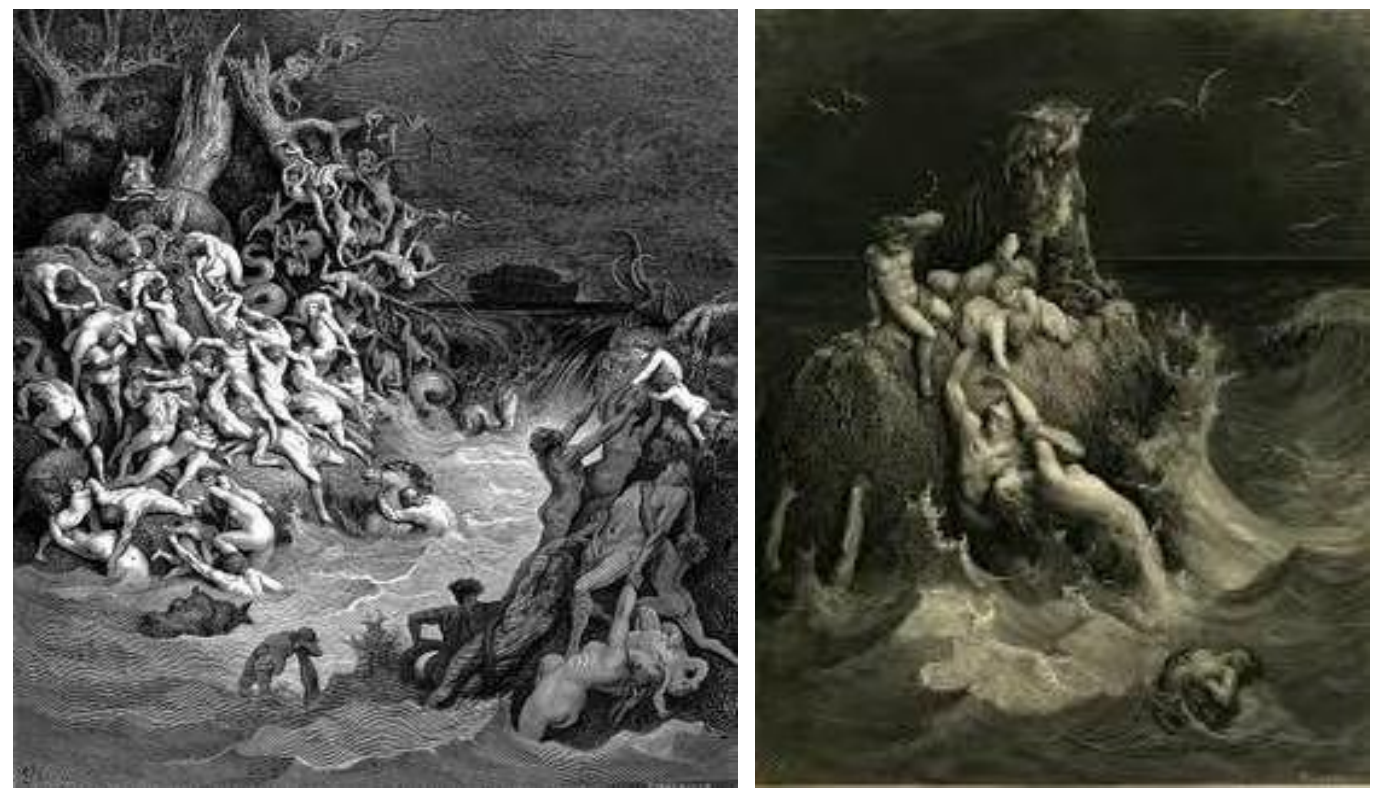

Görsel 12: Gustav Dore, Tufan, Kutsal Kitap Resmi, Gravür Bask1, Strazbourg, (1832-1883)

Görsel 13: Gustave Dore, The Deluge, $35 \times 44 \mathrm{~cm}$. Gravür, 1866, The Dore Bible Gallery, https://www.google.com/search?q=güstav+dore\&tbm= 10 Aralık 2018

4.yy. Erken Hıristiyan Döneminde, mermer kabartma olan Bizans lahitinin üzerinde: Nuh'un gemisi sandık şeklinde gösterilmiştir. Güvercinin Nuh'un gemisine gagasında zeytin dalıyla gemiye dönmesi karaya ulaştı̆ıının belirtisi olarak ifade etmekte ve yeni yaşamın başlangıcını haber vermektedir. (Görsel 14)

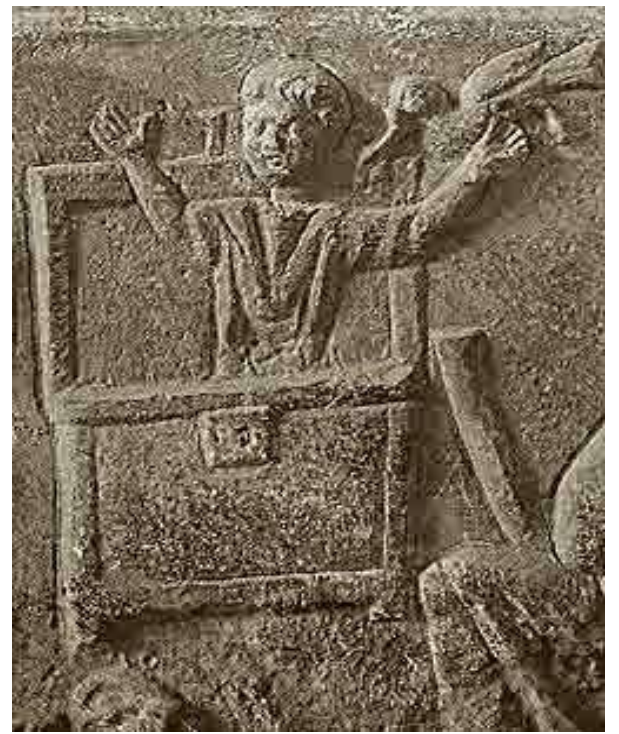

Görsel 14: Güvercinin Dönüşü, Mermer Kabartma Bizans Lahti Üzerinde, 4.yy. Erken Hıristiyan Dönem, Museo Civico, Velletri, İtalya,

https://www.google.com/search?safe==Museo10.12.2018

Vatikan Pontifici Sarayında, Tufandan sonra Nuh'un gemisinden çıkış konusunu anlatan Rafael'in ünlü eserinde: Nuh kırmızı bir pelerin takmış olarak tasvir edilmiş ve ailesinden dört kişi ile gemiden çıkan çift hayvanlar, hayvanların etrafında uçan güvercin, geminin bir bölümünün yer aldığı fresk bulunmaktadır. (Görsel 15) 


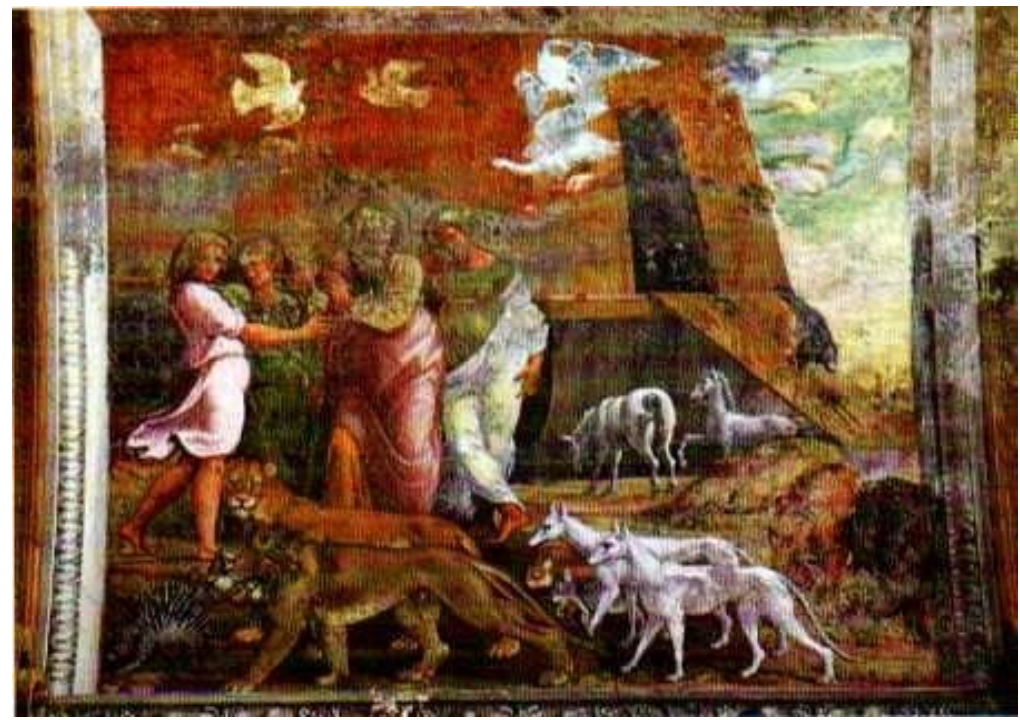

Görsel 15: Rafaello Sanzio, Nuh'un Gemisinden Çıkış, Vatikan Pontifici Sarayı, Fresko, 1517-1519 https://www.google.com/search?safe=strict\&rlz=10 Aralık 2018

Görsel 16 da, İtalyan ressam ve gravür sanatçısı Giovanni Benedetto Castiglione Nuh'un Gemisinin Önü, adlı Tufan resminde, yoğunluklu figür olarak hayvanları kullanılmışır. Kırmızı renkli bir kumaşla Hz. Nuh, yerde iç içe girmiş bir şekilde duran hayvanlara doğru yönelmiş ve sağ elinin işaret parmağıyla yeri göstermektedir. Çoğunluğunu yaban kuşlarının oluşturduğu kalabalık hayvan gurubunun içerisinde, keçi, köpek, koyun, eşek gibi evcil hayvanlar da yer almaktadır(Göğebakan, 2016, s.65).

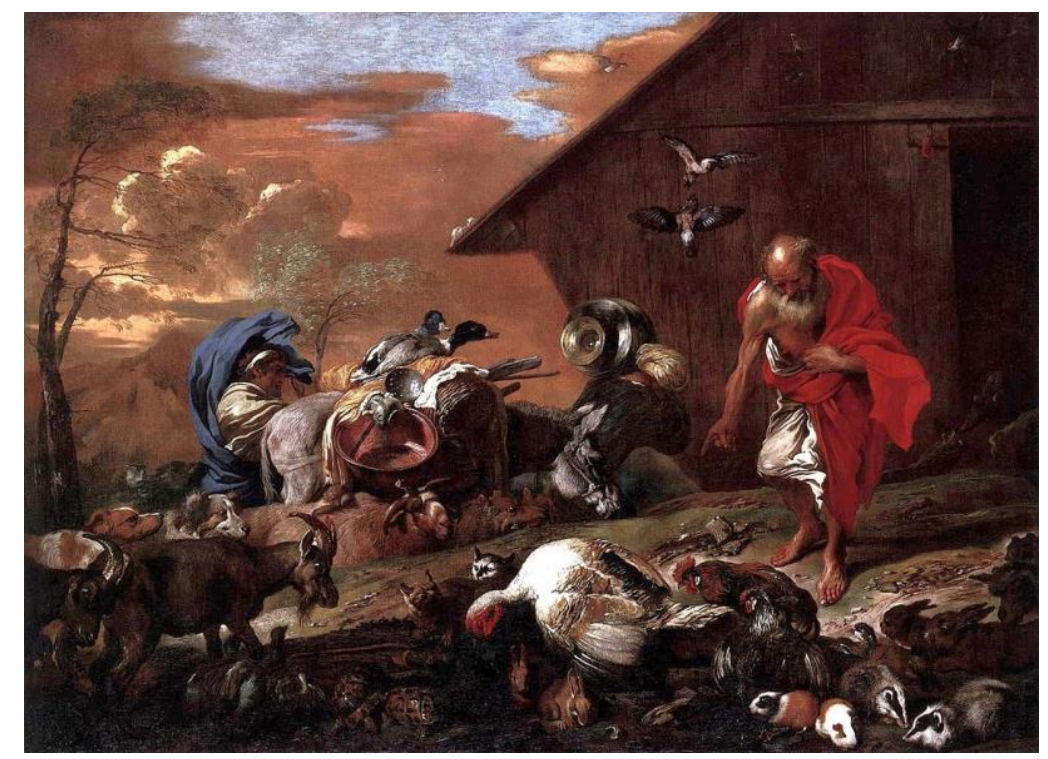

Görsel 16: Giovanni Benedetto Castiglione, Nuh’un Gemisi’nin Önü, 1650, Tuval Üzerine Yağlıboya, $145 \times 195 \mathrm{~cm}$. https://www.wga.hu/support/viewer/z.html

Michelangelo Buonarroti'nin, Sistina Şapelin tavan freskinde yer alan kompozisyonda Nuh'un kurban sunusu sahnesi, Nuh ve ailesi, sekiz kişi, karısı, gelinleri ve oğulları tasvir edilmiştir. Kurbanlık hayvanlar temayı belirleyen unsurlardır. Masanın altında yanan ateşe bakan, yerde çömelmiş arkası dönük yüzü görünmeyen figür, daha sonra Nuh'un lanetlediği oğlu olduğu düşünülmektedir.(Görsel 17) 


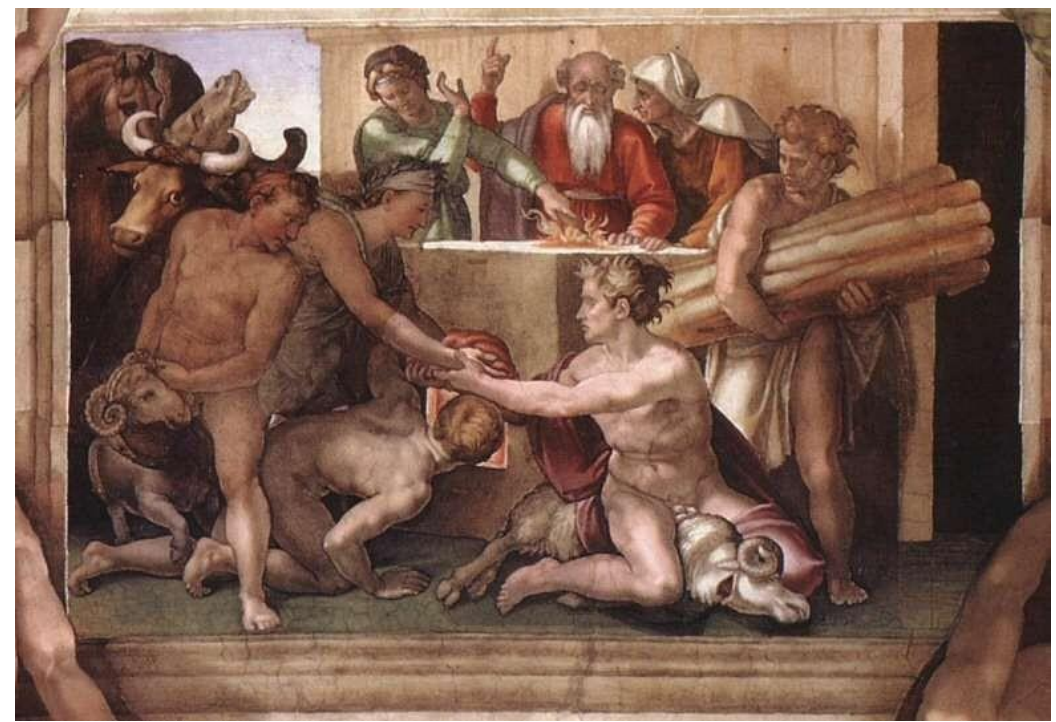

Görsel 17: Michelangelo Buonarroti, Nuhun Kurban Sunusu, Sixtinia Şapeli Floransa, Fresk, İtalya, 1508/1512, (http://www.artbible.info/art/large/71.html, 10 Aralık 2018)

John Martin, İngiliz romantizminin önemli isimlerinden resim, gravür ve illüstrasyon sanatçısıdır. Suların Çekilmesi isimli eserinde tufan sona ermiş, güneşli bir gün başlamıştır. Sularda çekilmiş ve güneşin kızıllığını vurduğu yalçın kayalar gün ışığına çıkmıştır. Nuh'un önceden gönderdiği kuzgun ve sonradan gönderdiği güvercin kayalıklarda konacak yer bulmuşlardır. Kaya parçaları arasında birikmiş suda, gövdesi suya gömülü, başının bir kısmı yüzeyde kalmış ölmüş bir insan figürü dikkat çekicidir (Sezer, 1993, s. 95). (Görsel 18)

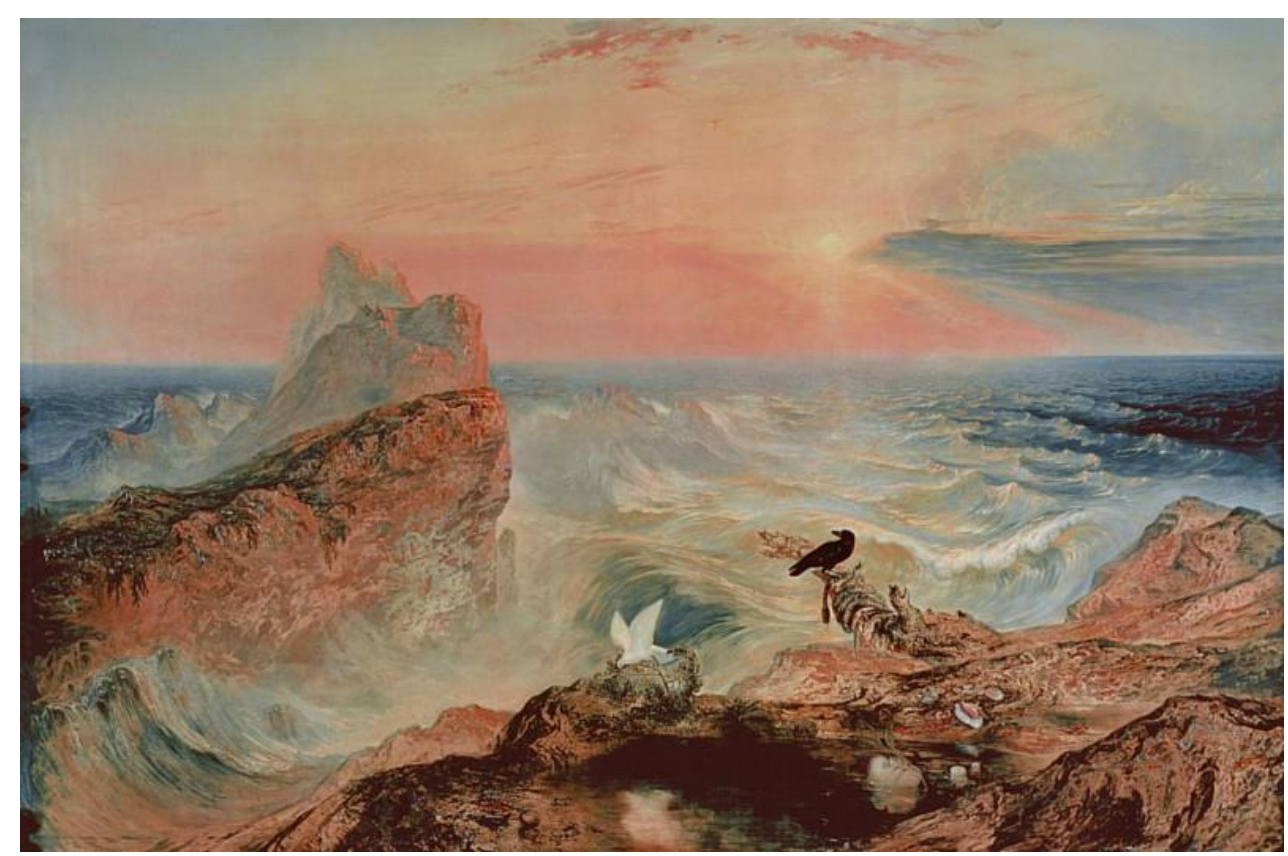

Görsel 18: John Martin, The Assuaging of the Waters, 143.5x219.1 cm. Tuval Üzerine Yağlıboya, 1840 https://www.google.com/search?q=John+Martin, 10 Aralık 2019

Sanatsal yansımalarındaki örneklerde Tufan konusu, tufanın akışına göre ikonografik olarak değerlendirilmiştir. Tufan konusunu ele alan sanatçıların eserlerinden kısıtlı örneklerle anlatılmaya çalışılmıştır. Konu akışında kullanılan örnekler: Tufanı, Geminin Yapımı, Hayvanların Girişi, Nuh Tufanı, Gemiye Güvercinin Dönüşü, Tufandan sonra Nuh'un Gemisinden Çıkışı, Nuh'un Kurban Sunusu ve Tufanın Sonu sahnesi sırası ile Tufan tasvir edilmiştir. Nuh Tufanında, Nuh Tevratta iyi bir 
insan olarak Tanrı tarafindan seçilmiş, ailesi ve hayvan türlerinden birer çiftle birlikte tufandan kurtarılmıştır. Sanatsal yansımalarındaki örneklerde Nuh, uzun beyaz saç ve sakalları olan yaşlı bir erkek, kırmızı pelerin ya da palto tarzı uzun giysileri ile sembolize edilmiştir.

Sanatçılar tufan konulu eserleri bazen karamsar işlerken, bazen de çok aydınlık ve umutlu işlemişlerdir. $\mathrm{Bu}$ dönemde yapılan eserler, sosyal olayları ve ekonomik çalkantıları, politik olayları, yeryüzünün karamsar ruh halini ve anlam kargaşasını sanata yansıtmışlardır. Sanatta anlatılmak istenilen olaylar zamana uyarak biçimde özde ve kompozisyonda da değişmektedir.

Tufan efsanesini, 1820'li yıllarda dünyadaki en ünlü eserlerden biri ve tartışmasız Japon sanatının en ikonik eseri, Katsushika Hokusai'nin Büyük Dalga, olarak adlandırılan Kanagawa'nın Büyük Dalgaları'nın da dahil olduğu, 36 Fuji Dağı Manzarası adlı ahşap baskı serisidir. Hokusai'nin dini inançlarına göre ölümsüz yaşamla ilişkilendirilen Fuji Dağı ölümsüzlük sırrının kaynağı olarak görülür. Serideki tüm eserlerde dağın bir görüntüsü vardır, ancak Fuji Dağı her zaman çerçeveye hükmetmesine rağmen, büyük bir dalga öndedir. (Görsel 19) (https://www.khanacademy.org/humanities/ap-arthistory/south-east-se-asia/30.04.2017).

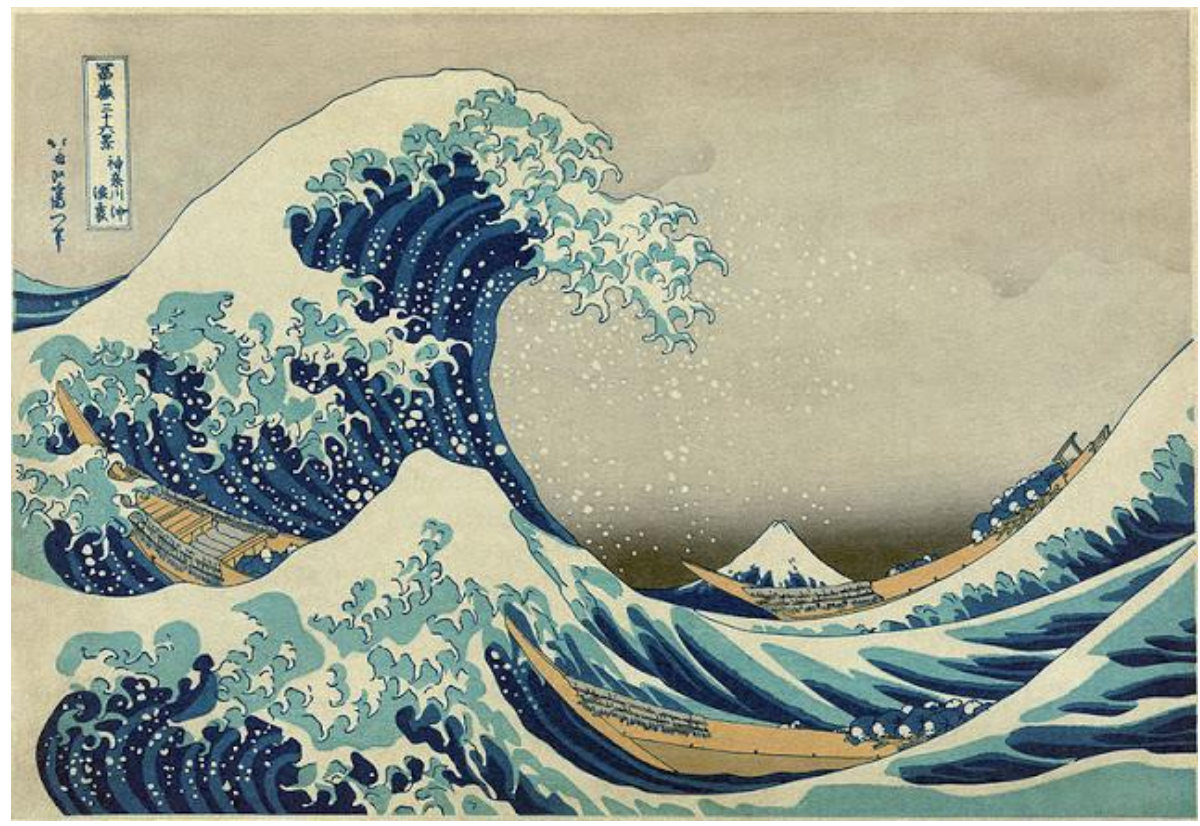

Görsel 19: Katsushika Hokusai, Büyük Dalga, Metropolitan Müzesi, New York, 1820 https://www.khanacademy.org/humanities/ap-art-history/south-east-se-asia/art/30.04.2017

İspanyol sanatçı Salvador Dali, 20. yy. batı sanatının ve gerçeküstücü sanat anlayışın en önemli temsilcilerindendir(1904-1989). İmgelemin yarattığ 1 bazı simgesel nesneler Dali'nin resimlerinin kaynağı olmuştur. Freud'un edebiyat, destan ve mitlerdeki kişiliklerin, kuşakların düşsel dünyalarındaki silinmez yerleri olduğuna yönelik inancını Dali de benimsemiştir. Gizli şeyler, bellek verileri psikolojik çapraşıklıklar, patolojik deformasyonlar sanatçının yaratım ögeleri olup, hayal ürünü imgeler onun çalışmalarında imgeleştirilmektedir İşte bu ögeleri sanatçı baskın bir sel felaketi görüntüsü içerinde vermiştir(Göğebakan, 2016, s.66).(Görsel 20) 


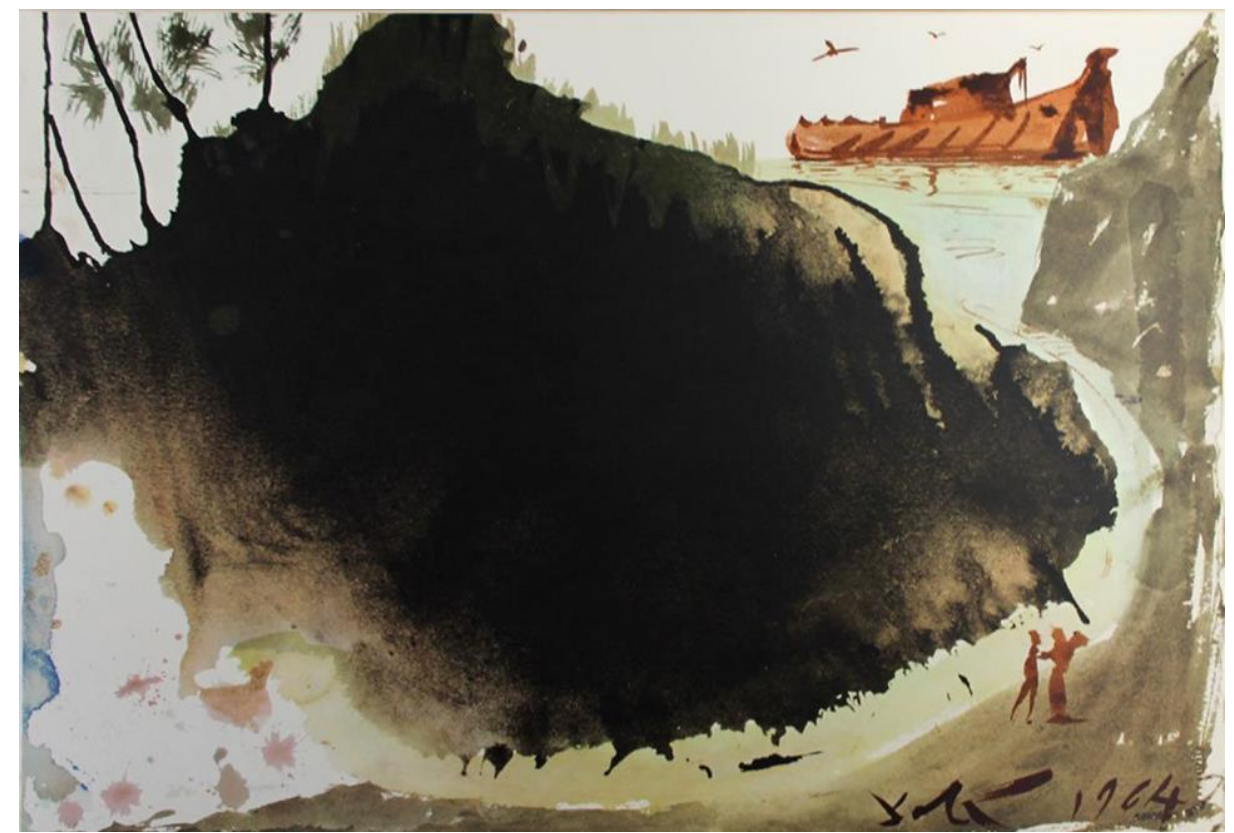

Görsel 20: Salvador Dali, Büyük Sel, Litografi, 1964

(Göğebakan, 2016, s.66)

Gerçeküstücü ressamlar arasında olan Nuri Abaç, mitolojiyi, masalsı ve gerçeküstücü-fantastik bir biçemle resimlemiştir. Günümüz sanatçılarından olan Nuri Abaç yağlıboya tuval resminde, Michelangelo'nun Tufan ya da Nuh'un Kurban Sunuşu adlı fresklerinde olduğu gibi konu din temalıdır. Nuh tufanı isimli resmini biçimsel ve konusal yönden masalsı, gerçeküstücü, fantastik bir biçimleme; özgün ifade ve çağdaş bir anlatıma ulaşan çok figürlü düzenlemeler ile anlatılmaktadır. Nuhun Gemisi adlı eseri, Necef Antik Yayınları'nın 1998 yılında yayınladığı "Nuri Abaç" kitabının 59. sayfasında yer almaktadır. (Görsel 21)

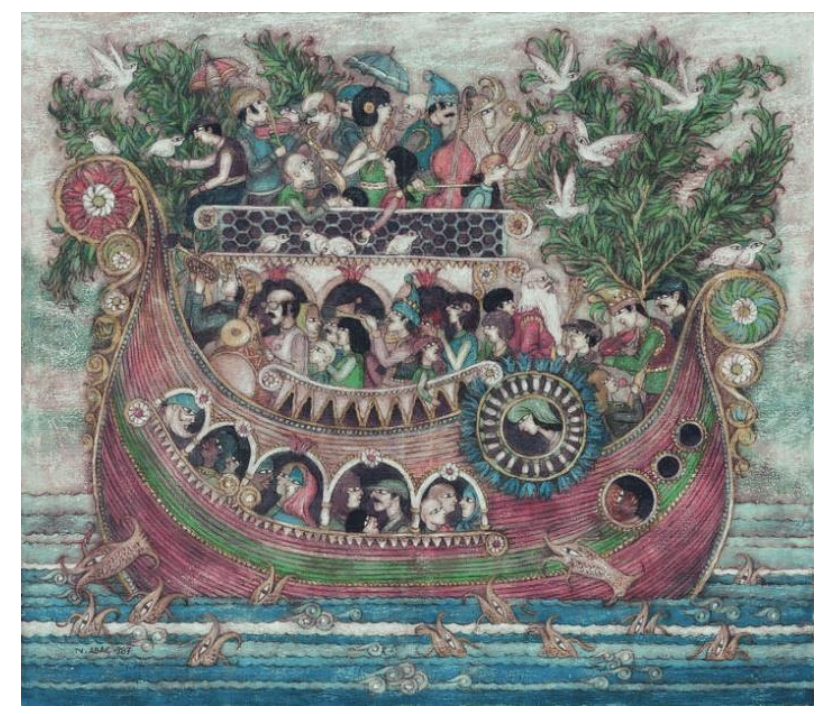

Görsel 21: Nuri Abaç, Nuh'un Gemisi, Tuval Üzeri Yağlıboya, 100x115 cm, 1987 (http://beyazart.com/v3/?page10.10.2018)

Tufan konusunu büyük dalgalar olarak tasvir eden sanatçılardan, Maggi Hambling, yağlıboya tabloları ve heykeli, dalgaların enerjisini ve gücünü ortaya çıkarmıstır. Maggi Hambling, deniz, her gün bir ritüelle başlayan takıntı haline gelmiştir ve şöyle demektedir: "Ağızları geniş olan Kuzey Denizi'nin dalgaları kıyılarımızı şiddetle tüketir, hareket eder, kükrer veya güler, her zaman baştan çıkarıcıdır. Yaşam ve ölüm, dalgaların zamansız ritminde esrarengiz bir biçimde var olur. Deniz zamanki gibidir, bu 
konuda hiçbir şey yapamazsınız. Ölüm gelecek, deniz gelecek. Sevgisiz dalgaları yaratmak için o kadar cesurca boya..” (Görsel 22), (http://www.maggihambling.com,http://mymodernmet.com/maggihambling-30.04. 2017).
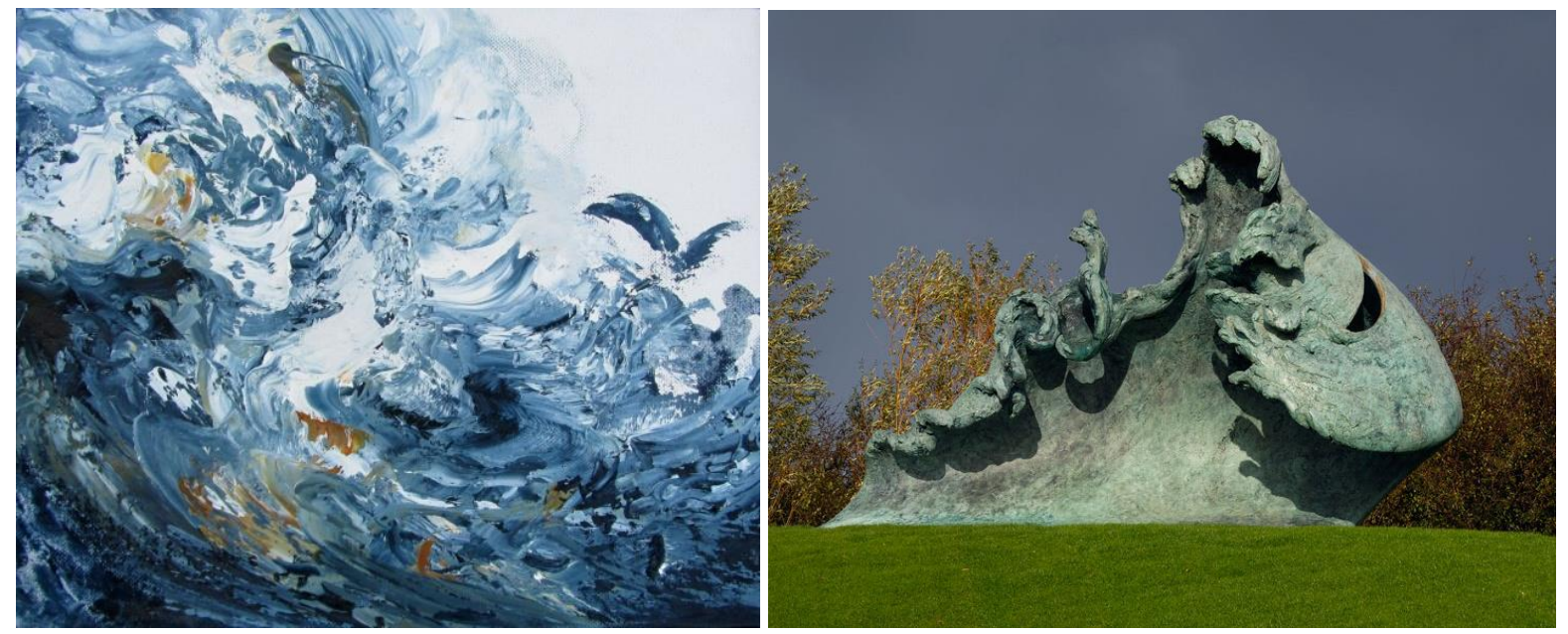

Görsel 22: Maggi Hambling, Yükselen Dalga, 2009

http://www.maggihambling.com, http://www.fitzmuseum.cam.ac.uk/gallery/30.04.2017

Sanatçılar kendi zamanındaki sanat anlayışına bağlı olarak, içinde yaşadığı sosyo-kültürel ortam, bağlı olduğu etik değerler, inanç ve dinlerinin etkisi altında eserlerini oluşturmaktadır. Tufan konusu fresk, resim, mozaik gibi farklı teknikler kullanılarak anlatımların dışında, seramik ve cam kullanılarak soyut bir anlatımla kendisini göstermektedir. Maggi Hambling, Karl Fulle, Mette Maya, Marsha Blaker ve Paul DeSomma, Denise Romecki, Ai Weiwei, Leyla Kubat gibi kimi sanatçılar seramik ve camla simgesel anlam ve yaratıcıklarını yükselen dalga, büyük dalga ve dalgalar gibi tasvir ederek anlatmışlardır.

Karl Fulle 1977 yılında Studium der Keramik an der Hochschule für industrielle Formgestaltung Burg Giebichenstein Halle (Saale), da seramik eğitimi almış ve AIC/IAC üyesidir. Büyük dalgaları seramik çamuru kullanarak üç boyutlu formla anlatmaya çalışan seramik sanatçısı parçalamayı, dalgaları ve kıvrım yaratmayı, eserlerini dinamik hale getirmeyi sevmektedir. Seramikten dalgalar Karl Fulle'nun önemli eserleri arasındadır. (Görsel 23)
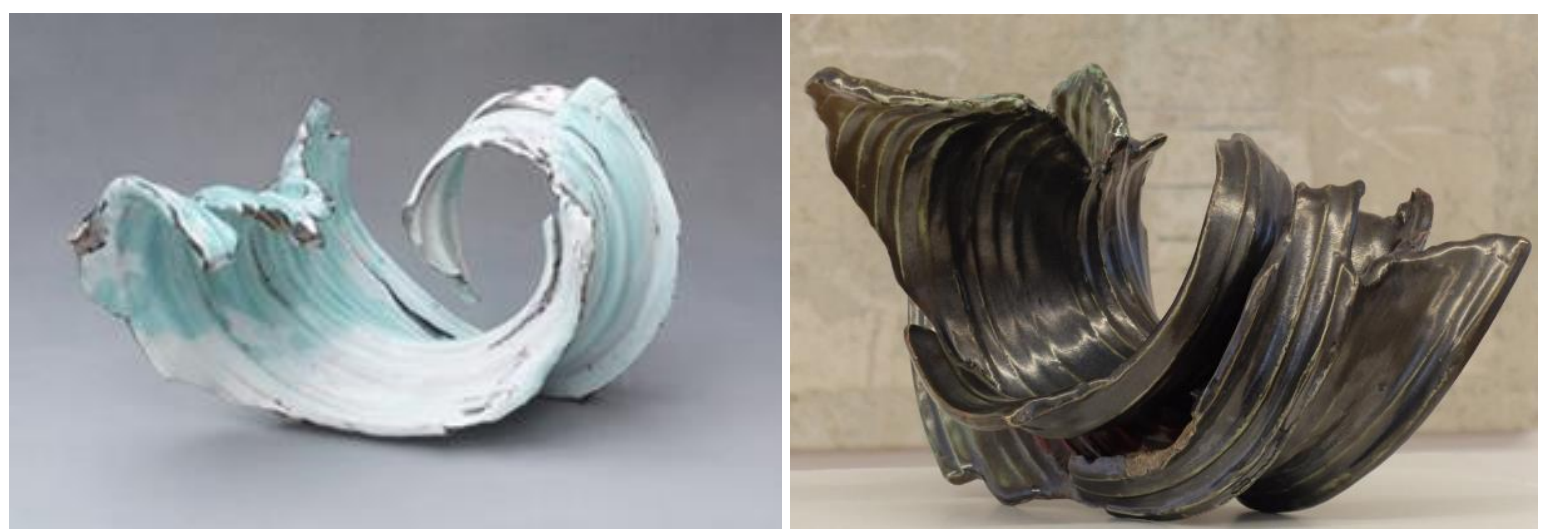

Görsel 23: Karl Fulle, Seramik Dalgalar, Rheinsberg, 2011

fulle-keramik de/, http://www.keramik-spuren.de/ 15.04.2017

Gregersen Mette Maya seramik sanatçıdır. Bir dönem eserlerinde dalgaları yoğun olarak kullanmıştır. Üç boyutlu seramik form olarak ele aldığı eserlerini şöyle yorumlamıştır; dalgalar önemlidir ve dalga zaman içindeki sabit hareketi yansıtmaktadır. Hiçbir şey aynı kalmaz ve zamandan etkilenmektedir. Yaşamda deneyimlerimiz bizi değiştirmektedir. Dalgalar kalıcı izler bırakır, ancak sağlam deneyimler anı sonsuza kadar götürmektedir. Dalga çalışmalarım kalıcı form bulan kısa adımlardır diye yorumlamışırır. Her dalga bir deneyimin cevabıdır.(Görsel 24) (http://www.mettemayagregersen.com,16.01.2017). 

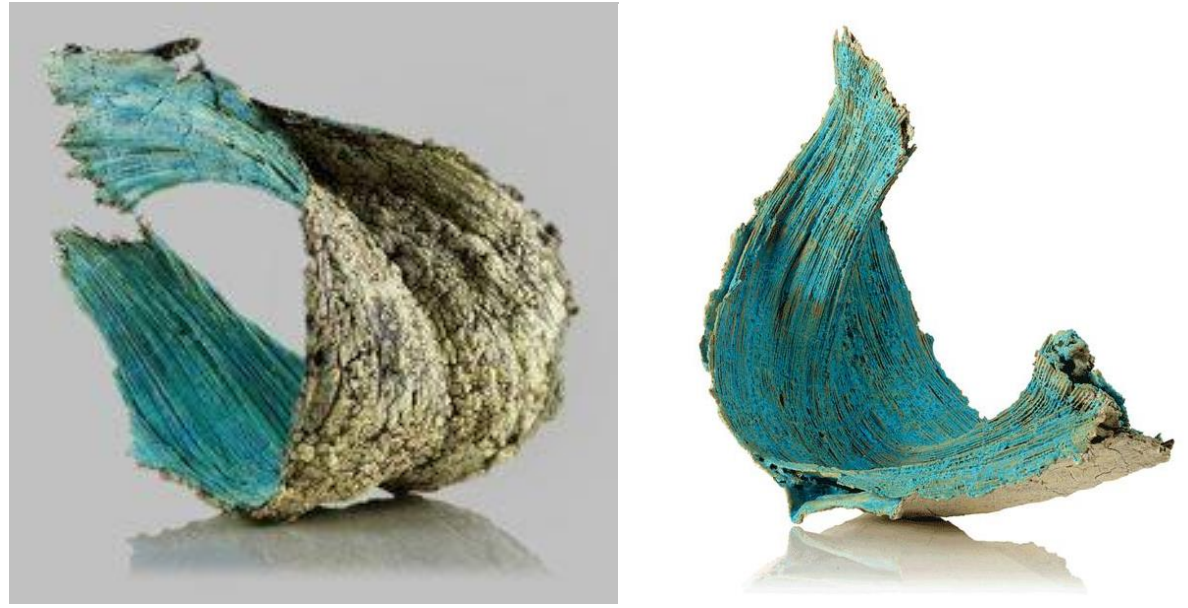

Görsel 24: Gregersen Mette Maya, Dalgalar

http://www.mettemayagregersen.com/wordpress/waves-2/, 16.01.2017

Kaliforniyalı sanatçılar Marsha Blaker ve Paul DeSomma, okyanusun muhteşem dalgalarından etkilenerek seramikten ve camdan etkileyici vazolar ve üç boyutlu formlar yapmışlar ve doğaya ve okyanuslara duydukları aşkı, yarattıkları eserlerdeki bu ihtişamlı dalgalara yansıtmışlardır. (Görsel25) (https://www.blakerdesommaglass.com.16.01.2017).

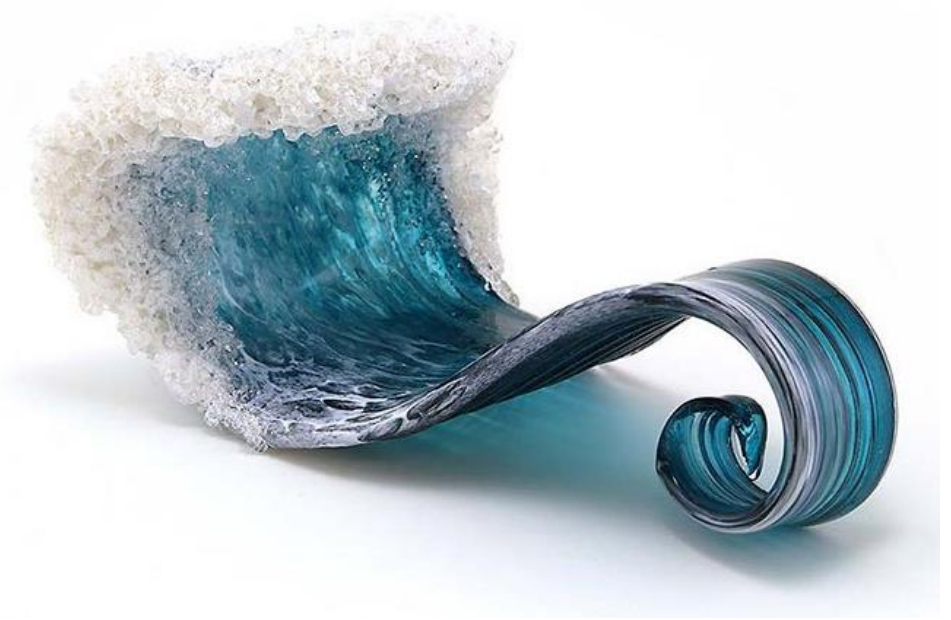

Görsel 25: Marsha Blaker ve Paul DeSomma, Cam, Okyanus Dalgalar, https://www.blakerdesommaglass.com.16.01.2017

Denise Romecki, doğanın tasarımını, döngülerini ve inceliklerini merak uyandırıcı bulmuştur. Farkındalığının artması ile okyanus dalgalarının gücünü ve güzelliğini seramik heykellere aktarmıştır. (Görsel 26) https://www.deniseromecki.com/portfolios/waves/16.01.2018 

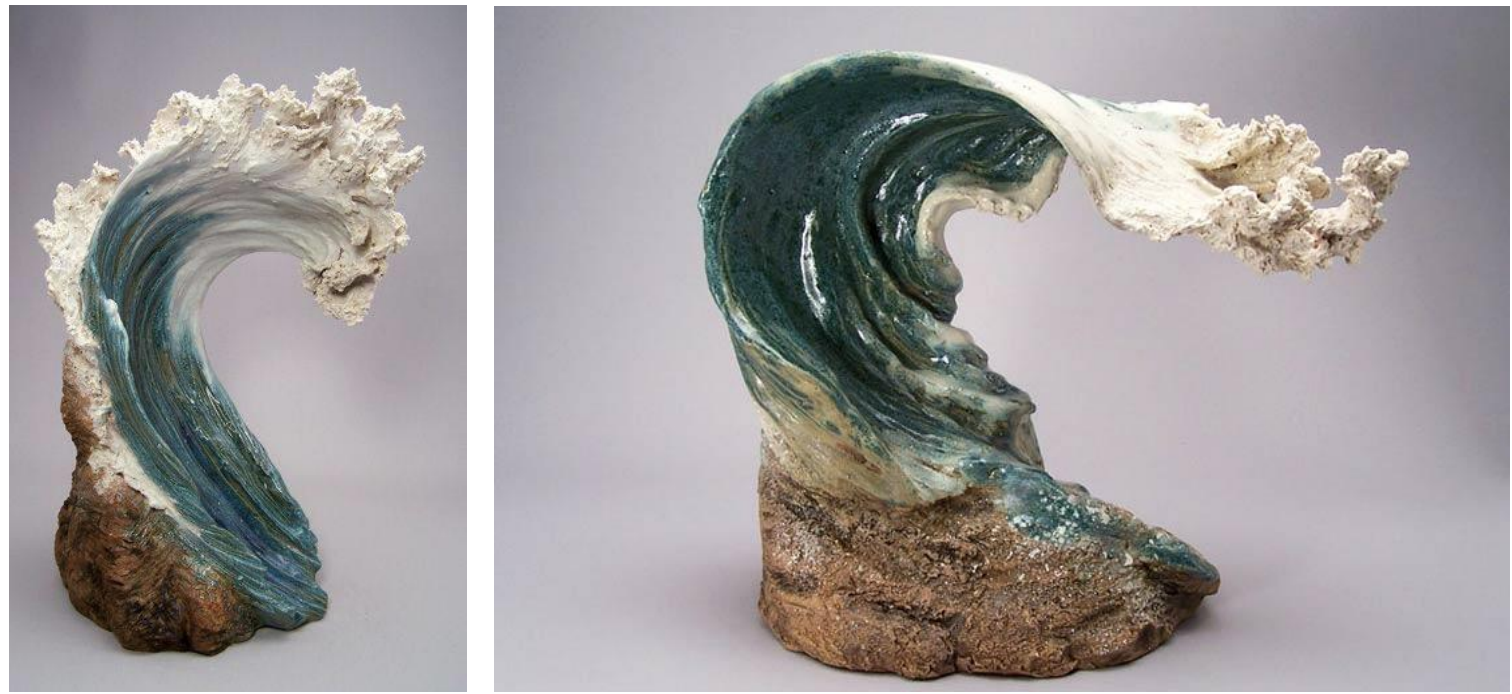

Görsel 26: Denise Romecki, Dalgalar

https://www.deniseromecki.com/portfolios/waves/16.01.2018

Ai Weiwei, Çinli bir sanatçıdır. Mimariden seramiğe uzanan geniş üretim yelpazesinde, günümüzün en yaratıc1 eylem gücünü pop art ve readymade'le ile bağdaştıran kültürel bir figür olarak ortaya çıkartmıştır. Yaşanmakta olan krizlerle, olaylarla bağlantılı hareket aracılığıyla politik aktivitizm ve çağdaş sanat arasındaki ayrımı belirsizleştirmiştir. Toplumsal değişimin sanat üretiminin temel bileşimlerinden biri olduğunu kabul eden bu benzersiz sanatçı, otuz yılı aşkın zamandır bize dünyayı keşfetmek, anlamak ve yorumlayabilmek için yeni yollar sunmuştur. Ai Weiwei 2004'te Hint Okyanusu'nda meydana gelen yıkıcı deprem ve tsunaminin hemen ardından yarattığı dalga, sanatçının güncel olaylar üzerinde düşünürken geleneksel dilleri kullanışının bir örneğidir. (Görsel 27)

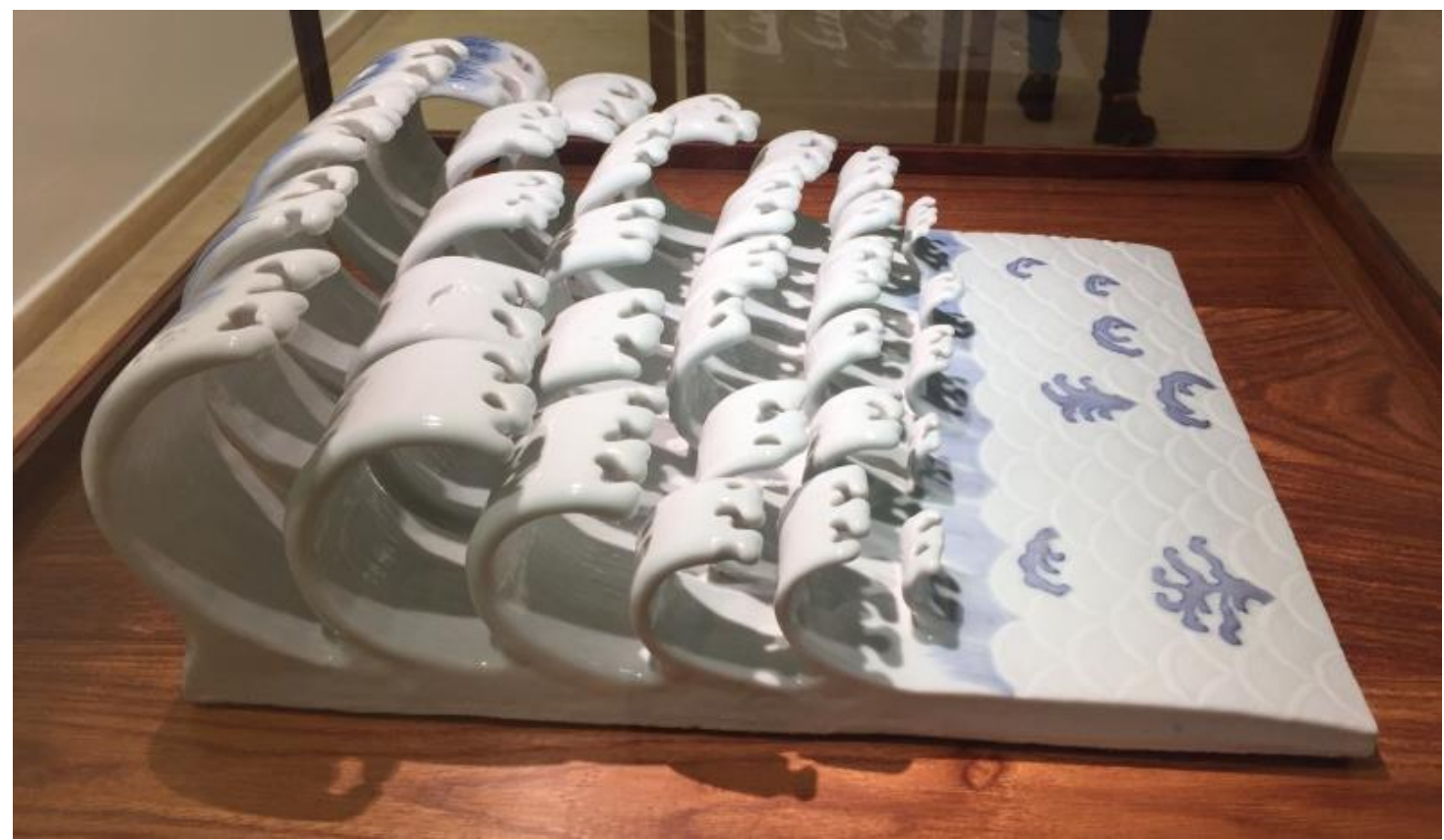

Görsel 27: Ai Weiwei, Dalga, Porselen, Sakıp Sabancı Müzesi, 2005 Fotoğraf: Leyla Kubat, Aralik 2017

Sanatçının yaşadığı somut ve soyut olaylar ve duygular onun üretmesi için herşeydir. Sanatçı elde ettiği tüm kişisel edinimlerin sonucunda üretebilmektedir. Konu, kültürle ve bilgiyle doğru orantılı olarak gelişir, büyür, derinleşir (Erinç, 1998, s. 17). Sanatçılar yaşadıkları dönemin olaylarını, içinde yaşadıkları sosyo-kültürel ortamı, bağlı oldukları etik değerleri, inanç ve dinlerinin etkisi altında sanat görüşlerini eserlerine yansıtmaktadırlar. Günümüzdeki yaşanan toplumsal olaylarda sanatçıların dikkatini 
çekmektedir. Dünyayı etkileyen toplumsal olaylardan Avrupa'ya geçmeye çalışan mültecilerin denizdeki yaşam mücadeleleri olmuştur. Ai Weiwei, Almanya'nın başkenti Berlin'deki Konzerthaus Konser Evi'nin sütunlarını Avrupa'ya gitmek isteyen mültecilerin kullandığı 14 bin can yeleğiyle kaplamıştır. Sanatçı can yelekleri giydirdiği sütunların arasına üstünde Güvenli Geçiş, yazan şişme bir bot yerleştirerek olaya dikkat çekmek istemiştir.

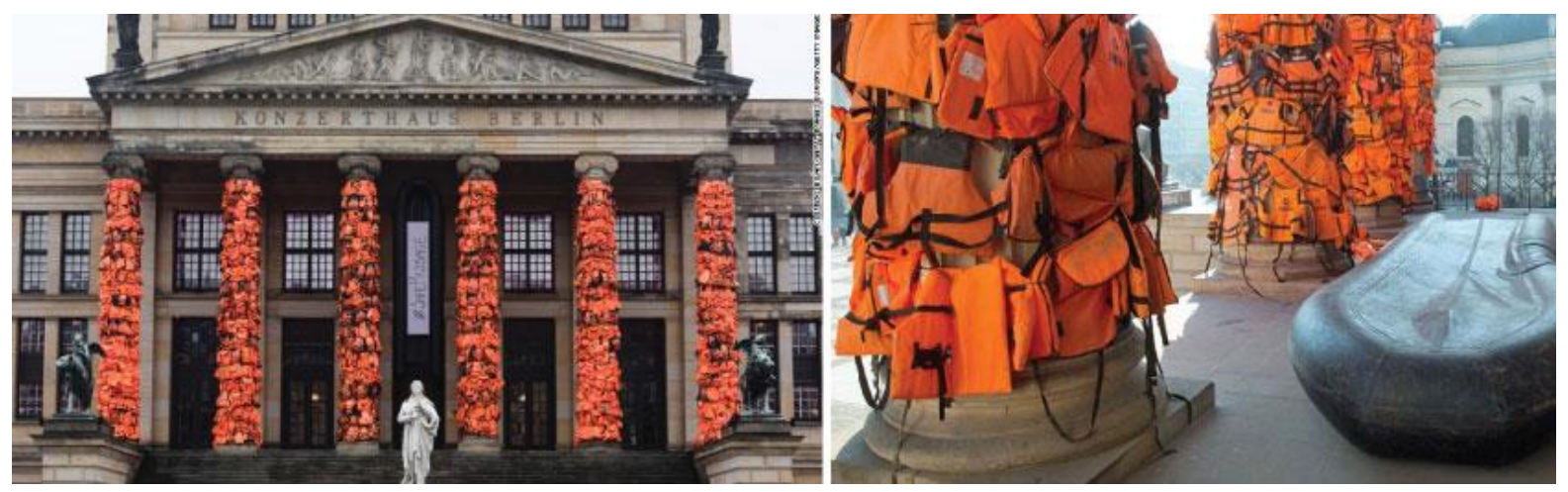

Görsel 28: Ai Weiwei, Güvenli Geçiş,

www. aykiri-akademi-sanat-gorsel-sanatlar/ai-weiwei, 1.12.2019

Dünyayı etkileyen olaylardan biri de Türkiye kıyılarında olmuştur. Milyonlarca insan, güvenlik donanımı olmayan, bakımsı, eski teknelerle hayatta kalabilme mücadelesi ile ölümün varlı̆̆ını tehlikeli deniz yolculuklarına çıkmıştır. Botlarda umuda yolculuğunu tamamlayamayan birçok insan aynı sona maruz kalmıştır. Dünyayı sarsan mülteci dramlarında, lastik botların batmasıyla geriye akıllardan yokolmayacak kıyıya vurmuş çocuk cesetleri kalmıştır.. (Görsel 28)

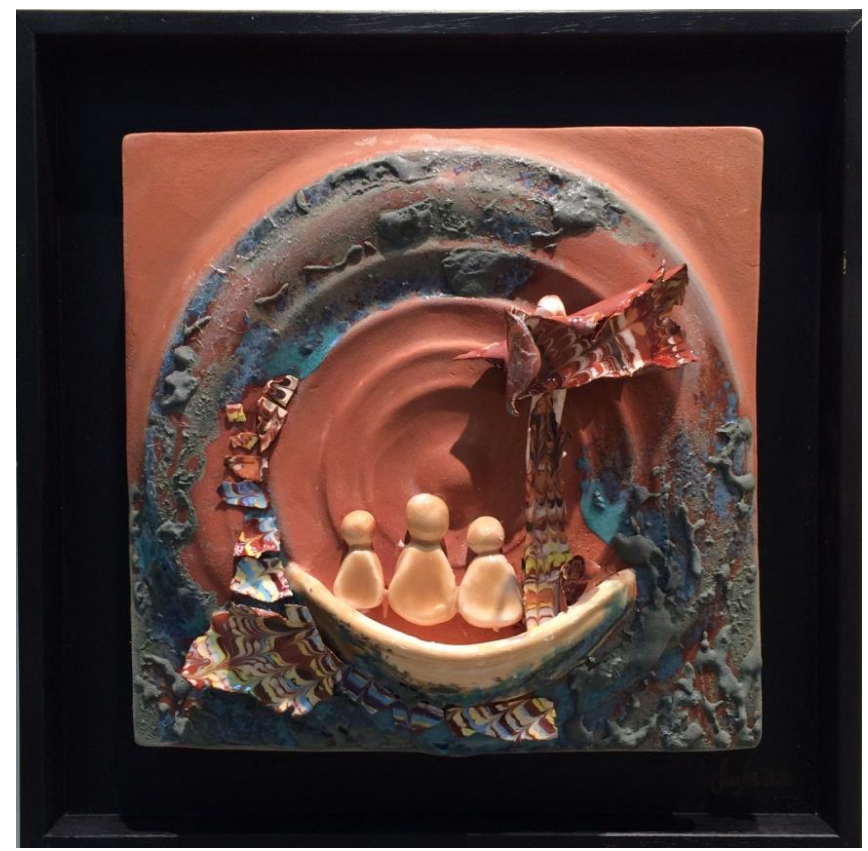

Görsel 29: Leyla Kubat, Tufan ve Göç, Seramik, Kırmızı Çamur, Akıtma Dekoru, 30x30 cm, 1050 C , 2016

Fotoğraf: Leyla Kubat, 2016

\section{SONUÇ}

Uygarlıkların mitolojisinde Tufan tekrarlanan mitlerden olarak bilinmektedir. Tufan mitolojisinin özü sudur. Suyun, mitolojide yaratılışın ayrılmaz parçası olduğu kabul edilmiştir. Yaratılış mitosları kültürlerde çeşitlilik gösterselerde, yaratılışın suyla varolduğu kabul edilmiştir. Tufan felaketiyle görülen suyla ölüm ve sudan kurtulmayla başlayan yeni hayat, yokolma-varolma deviniminde yeniden 
varolmaya ait simgeleştirmedir. Birçok kültürde tufan efsanesinin nedeni kimi zaman tanrıların çılgınlığı, tanrının insanları yok etme isteği, dünyanın yenilenmesi, kimi zamansa yeni başlangıçların olduğu şeklinde anlatılmaktadır. Birçok bölgede görülmesi, tufanın evrensel olduğunu düşündürmektedir. Tufan, yaşandığı bölge ile değil, tufanın nedeni ve sonuçlarının etkisi ile evrensel bir özellik taşımaktadır. Nedenlerinin ve sonuçlarının sanatçılar tarafından sanatsal yaratılarına imkan hazırlamasına ve kültürel farklılıkların gelecek kuşaklara aktarılmasına olanak sağlamaktadır. Sanatçılar tarafından ele alınan tufan konulu eserler, sanata yansımasının nedenli olduğunu ortaya çıkartmış, sanatçının toplumsal ve bireysel değişiminin etkilerini göstermektedir. Tufan konusunu işlemek, anlatmak istedikleri kompozisyonlar içinde kendilerini özgürce ifade etmek anlamına gelmektedir. Sanatın gelişmesine ve zenginleşmesine önemli katkısı olan tufan mitolojisi, kültürel değerlerin devamlılığını da sağlamaktadır. Sanat eserleri tarihi bilgilerin eksik olduğu dönemlerde bilgileri tamamlamamıza yardım etmiştir ve etmektedir.

Sanatsal yansımalarındaki örneklerle tufan konusunu ele alan sanatçıların eserlerinden, konu akışına göre kısıtlı örneklerle anlatılmaya çalışılmıştır. Tufanı, Nuh'un Gemisi, Geminin Yapımı, Gemiye Hayvanların Girişi, Nuh Tufanı, Gemiye Güvercinin Dönüşü, Tufandan sonra Nuh'un Gemisinden Çıkışı, Nuh'un Kurban Sunusu ve Tufanın Sonu sahnesi sırası ile seçilmiş örneklerle değerlendirilmiştir. Tufan günümüz sanatına, çağdaş dünya sanatına bir derinlik katmaya devam etmektedir. Sanatçılar kendi zamanındaki sanat anlayışına bağlı olarak, fresk, resim, mozaik gibi farklı teknikler kullanılarak anlatımların dışında, tufan konusunu seramik ve cam kullanılarak soyut bir şekilde anlatmaktadırlar. İnsan yaşamaya devam ettiği sürece, ortak kültürler, mitler de, sanat da, buna bağlı sanat eserleri de sanatçılar tarafindan var olmaya, yaşamaya devam edecektir ve ifadesel özelliklerinin yansitılmasında sanatçıya geniş olanaklar sunacaktır. Sanatçı bilgi birikimi, sanat görüşü ve anlatım tarzıyla, plastik bir dille konuyu ele alacak ve almaktadır. Bunlar insanoğlunun kültürel varlığının farkındalığının oluşturulmasına yardım edecektir.

Milyonlarca yıl önce yaşanan Tufan konusu günümüzdeki varlığını farklı şekilde göstermeye devam etmektedir. Tufan kavramının sanatta daha çok yer bulmasının ve betimlenmesinin teknoloji ile beraber gelişen ancak kaynakları azalan dünyanın doğanın değerinin anlaşılmasında, kaybedilen yaşamların yeniden canlanmasında ve sorgulanmasında önemli bir etkisi olabilir mi? Sanatın bu konuya dokunuşlarının katkısı nasıl arttırılabilinir? gibi benzer sorular sanatla cevap aramaya devem edecektir.

\section{KAYNAKÇA}

Aksoy, B. (1987). Nuh'un gemisi ve tufan, insanlık yolu yayınları. Ankara.

And, M. (2007). Minyatürlerle Osmanl-İslam mitologs. İstanbul: YKY.

Aylk, E. (2010). Postmodernizm sürecinde görsel sanatlarda mitolojik yapıt çözümlemeleri. Yayımlanmamış yüksek lisans tezi, Ankara.

Bahadır, Ü. (2013). Hıristiyan ikonografisinde Nuh Tufanı. Yayımlanmamış yüksek lisans tezi, Gazi Üniversitesi, Sosyal Bil. Ens.,Sanat Tarihi ABD, Ankara.

Bayat, F. (2007). Türk mitolojik sistemi. İstanbul: Ötüken Neşriyat.

Bucaille, M. (1991). Tevrat İnciller ve Kur'an. çvr. M. A. Sönmez, Ankara.

Campbell, J. (1998). Doğu mitolojisi tanrının maskeleri. çev. Kudret Emiroğlu (İkinci Baskı). Ankara: İmge Kitabevi.

Can, Ş. (1997). Klasik Yunan mitolojisi. İstanbul: İnkılâp Kitabevi.

Cömert, B. (2006). Mitoloji ve ikonografi. Ankara: De- Ki Basım ve yayım Ltd. Şti.

Çı̆̆, M. İ. (2008). Gllgamış tarihte ilk kral kahraman. (Sekizinci Baskı). İstanbul: Kaynak Yayınları.

Çınar, G. (2006). Heykel ve mitoloji, Yayınlanmamış yüksek lisans tezi, İstanbul.

Deliduman, C., Sezer, A. (2015). Resim sanatında Nuh Tufanı. Idil, 5(19).

Eliade, M. (1993). Mitlerin özellikleri. çev. Sema Rifat. İstanbul: Simavi Yayınları.

Erhat, A. (1972). Mitoloji sözlügü. Ankara: Remzi Kitapevi.

Erinç, S. (1998). Sanatın boyutları, İstanbul: Çınar Yayınları.

Gezgin, İ. (2011). Sanatın mitolojisi. (İkinci Baskı). İstanbul: Sel Yayıncılık. 
Göğebakan, Y. (2016). İnanç sistemleri içerisinde yer alan tufan miti ve bunun resim sanatına yansimaları. 55-72

Hamılton, E. (1997). Mitologya. çev. Ülkü Tamer. İstanbul: Varlık Yayınları.

Hançerlioğlu, O. (2000). Dünya inançları sözlüğ̈̈. İstanbul: Remzi Kitabevi.

Harman, Ö. F. (1999). Kitab-ı Mukaddes ve diğer dinlere göre Hz. Nuh ve Tufan. Hz Nuh’tan Günümüze Cizre Sempozyumu, İstanbul.

Hooke, S. H. (1995). Ortadoğu mitolojisi. Ankara: İmge.

Köksoy, M. (2002). Nuh Tufanı ve Sümerlerin kökeni. Yeni Avrasya: Ankara

Kramer, S. N. (2002). Sümerler. Kabalc1: İstanbul.

Kramer, S. N. (2005). Tarih Sümerde başlar. çev. M. İ. Çı̆̆. TTK: Ankara.

Madra, B. (2004). Resme bakan yazılar. (Editör, Ali Artun) (Birinci Bask1). Ankara: Galeri Nev.

Necatigil, B. (1969). http://www.belgeler.com/blg/1tj//behcet-necatigil-mitologya

Ögel, B. (1989). Türk mitolojisi 1. Ankara: TTK.

Rosental, M., P. Yudin (1997). Felsefe sözlüğü. çev. Aziz Çalışlar. İstanbul: Sosyal Yayınlar.

Rosenberg, D. (2003). Dünya mitolojisi. Büyük destan ve söylenceler Antolojisi. İstanbul.

Sarıkçığlu, E. (2011). Dinler tarihi. Isparta.

Sezer, A. (2017). Resim sanatinda Nuh Tufani. Yayınlanmamış sanatta yeterlik tezi. Gazi Üniversitesi, GSE, Ankara.

Şara, N. (2016). http://blog.milliyet.com.tr/01.12.2016

Tansuğ, S. (1983). Karşıtı aramak. (Birinci Baskı). İstanbul: Arkeoloji ve Sanat Yayınları.

Tecimer, Ö. (2005). Sinema modern mitoloji. 1. Baskı. İstanbul: Plan B İletişim, Tasarım, Tanıtım, Yayınc1lik ve Yapımc1lık San.

Turgut, İ. (1990). Felsefe ve sanat, sanatta anlam ve biçim. (Birinci Bask1). İstanbul: Ara Yayıncılık.

Tükel, U., Arsal, S. Y. (2014). Sözden imgeye bati sanatinda ikonografi. (Birinci Baskı). İstanbul: Kabalcı Yayıncılik.

Yakaryılmaz, N. (2009). Türk mitolojisinin resmi. Yayımlanmamış yüksek lisans tezi. Ankara.

Yılmaz, M. (2004). Sanatin felsefesi felsefenin sanatı. (Birinci Bask1). Ankara: Ütopya Yayınevi.

Yonar, G. (2015). Yaratılış mitolojileri, altı medeniyet altı yaratılış hikâyesi. İstanbul: Ötüken Neşriyat.

Ulutürk, M. (20139. Yeryüzünde neslin tek bir insanla yeniden başlamasının örneği olarak hint mitolojisinin nuh'u; manu ve tufan olayı. Uluslararası Hz. Nuh ve Cudi Dağı Sempozyumu, Şırnak.

https://www.academia.edu/13420947/Hint_Mitolojisinin_Nuhu_ManuveTufanOlay/ E.T. 15.112019

http://tr.wikipedia.org/wiki/Tufan, E.T. 09 Aralık 2015

http://www.artbible.info/art/large/71.html, E.T. 09 Aral1k 2015

https://www.khanacademy.org/humanities/ap-art-history/south-east-se-asia/ E.T. 30.04.2017

http://www.maggihambling.com, E.T. 30.04. 2017

http://www.fitzmuseum.cam.ac.uk/gallery/thewave, E.T. 30 Nisan 2017

http://mymodernmet.com/maggi-hambling-breaking-waves/ E.T.30 Nisan 2017

http://www.mettemayagregersen.com/wordpress/waves-2/, E.T.16.01.2017

\section{GÖRSEL LISTESI}

Görsel 1: Tufan, Ruks Museum, Amsterdam,1450-1499

Görsel 2: Peter Paul Rubens, Deucalion ve Pyrrha, 1636, 26.5×41.5 cm

Görsel 3: Tufan, Manu'nun Teknesinin Tasviri, Lord Vishnu'nun Matsya-Avatar

Görsel 4: Taşkın Efsanesi, Nanabozho, Kuzey Amerika Hint Masalları, Ojibwe'daki, 1905

Görsel 5: Zûbdetut- Tevârih, İslam Minyatür Sanat1, Nuh'un gemisi, 56,5x32x5 cm. Kâğıt Üzerine Suluboya Tekniği, TİEM 1973

Görsel 6: Kısasü'l-Enbiya, İslam Minyatür Sanat1, Nuh'un Gemisi'nin Kesiti, 
Görsel 7: Raffaello Sanzio, Nuh'un Gemisinin Yapımı, Vatikan Pontifici Saray1, Fresk, 1517-1519

Görsel 8: Jacoppo Bassano, Nuh’un Gemisinin Yapımı,124x163 cm. Tuval Üzerine Yağlıboya, 16. yy.

Museedes Beaux-Arts, Marsilya, Fransa

Görsel 9: Jacoppo Bassano, Nuh'un Gemisine Hayvanların Girişi, Madrid Prado Müzesi, İspanya, Yağliboya,

1570

Görsel 10: John Martin, Tufan, Yale University, Tuval Yağlı Boya, 1834

Görsel 11: Michelangelo Buonarroti, Nuh Tufanı, Fresko, $(280 \times 560 \mathrm{~cm})$, Museum Sistine Şapel Tavanı, Vatikan, 1508-1512

Görsel 12: Güstav Dore, Tufan, Kutsal Kitap Resmi, Gravür Bask1, Strazbourg (1832-1883)

Görsel 13: Gustave Dore, The Deluge, 35x44 cm. Gravür, 1866, The Dore Bible Gallery, Philadelphia

Görsel 14: Güvercinin Dönüşü, Mermer Kabartma Bizans Lahti üzerinde, 4.yy. Erken Hıristiyan Dönem, Museo Civico Velletri, İtalya

Görsel 15: Rafaello Sanzio, Nuh'un Gemisinden Çıkış, Vatikan Pontifici Sarayı, Fresko, 1517-1519

Görsel 16: Giovanni Benedetto Castiglione, Nuh'un Gemisi'nin Önü, 1650, Tuval Üzerine Yağlıboya, $145 \times 195 \mathrm{~cm}$.

Görsel 17: Michelangelo Buonarroti, Nuhun Kurban Sunusu, Sixtinia Şapeli Floransa, Fresk, İtalya, 1508/1512

Görsel 18: John Martin, The Assuaging of the Waters, 143.5x219.1 cm. Tuval Üzerine Yağlıboya, 1840

Görsel 19: Katsushika Hokusai, Büyük Dalga, Metropolitan Museum of Art, New York, 1820

Görsel 20: Salvador Dali, Büyük Sel, Kağıt Üzerine Litografi, 1964

Görsel 21: Nuri Abaç, Nuh'un Gemisi, Tuval Üzeri Yağlıboya, 100x115cm, 21. Çağdaş ve Modern Sanat

Müzayedesi, 1987

Görsel 22: Maggi Hambling, Yükselen Dalga, 2009

Görsel 23: Karl Fulle, Seramik Dalgalar, Rheinsberg, 2011

Görsel 24: Gregersen Mette Maya, Dalgalar

Görsel 25: Marsha Blaker ve Paul DeSomma, Cam, Okyanus dalgalar

Görsel 26: Denise Romecki, Dalgalar,

Görsel 27: Ai Weiwei, Dalga, Porselen, Sakıp Sabancı Müzesi, 2005

Görsel 28: Ai Weiwei, Güvenli Geçiş,

Görsel 29: Leyla Kubat, Tufan ve Göç, Seramik, Kırmızı Çamur, Akıtma Dekoru, 30x30 cm, 1050 C , 2016

\section{GÖRSEL KAYNAKÇA}

Görsel 1: https://www.google.com.tr/search?q=Anoniem-De_zondvloed, E.T.09 Aralık 2015

Görsel 2 : https://www.museodelprado.es/en/the-collection/art-work E.T.09 Aral1k 2015

Görsel 3: https://en.m.wikipedia.org/wiki/Flood_myth, E.T. 09 Aralık 2015

Görsel 4: https://en.wikipedia.org/wiki/Flood_myth, E.T. 09 Arallk 2015

Görsel 5: https://www.google.com/search?q=nuhun+gemisiZ.ûbdetu+t-+Tevârih, E.T. 07 Ocak 2019

Görsel 6: https://commons.wikimedia.org/wiki/Category:Noah's_Ark_in_miniatures, E.T. 09 Aralık 2019

Görsel 7: https://www.google.com/search?q=Raffaello+Sanzio,+Vaticano+Pontifici+Saray1, E.T. 09 Aralık 2015

Görsel 8: https://www.unique-canvas.com/artprints/jacopo-bassano-artwork E.T.09 Aralik 2015

Görsel 9: http: //www.museodelprado.es/en/the-collectin/online-gallery, E.T. 09 Aralık 2015

Görsel 10: https://tr.wikipedia.org/wiki/Dosya:Martin, John - The Deluge-1834.jpg, E.T 09 Aralik 2015

Görsel 11: http://www.artbible.info/art/large/71.html, E.T. 09 Aralık 2015 
Görsel 12: https://www.google.com/search?q=güstav+dore\&tbm=E.T.10 Aralık 2018

Görsel 13: https://www.google.com/search?q=güstav+dore\&tbm= E.T. 10 Aralık 2018

Görsel 14: https://www.google.com/search?safe==Museo+Civico+Velletri, E.T. 10 Aralık 2018

Görsel 15: https://www.google.com/search?safe=strict\&rlz= E.T. 10 Aralık 2018

Görsel 16: https://www.wga.hu/support/viewer/z.html E.T.09 Aralık 2015

Görsel 17: http://www.artbible.info/art/large/71.html, E.T. 10 Aralık 2018

Görsel 18: https://www.google.com/search?q=John+Martin, E.T. 10 Aralık 2019

Görsel 19: https://www.khanacademy.org/humanities/ap-art-history/south-east-se-asia/art/ 30.04.2017

Görsel 20: Göğebakan, 2016, s.66

Görsel 21: http://beyazart.com/v3/?page E.T. 10.10.2018

Görsel 22: http://www.maggihambling.com, http://www.fitzmuseum.cam.ac.uk/gallery/ E.T. 30.04.2017

Görsel 23: fulle-keramik de/, http://www.keramik-spuren.de/ E.T. 15.04.2017

Görsel 24: http://www.mettemayagregersen.com/wordpress/waves-2/, E.T. 16.01.2017

Görsel 25: https://www.blakerdesommaglass.com. E.T.16.01.2017

Görsel 26: https://www.deniseromecki.com/portfolios/waves/ E.T.16.01.2018

Görsel 27: Fotoğraf: Leyla Kubat, Aralık 2017

Görsel 28: www. aykiri-akademi-sanat-gorsel-sanatlar/ai-weiwei, E.T. 1.12.2019

Görsel 29: Fotoğraf: Leyla Kubat, 2016 